مقايسه روشهاى برنامهريزى بيان زن و ركرسيونهاى يارامتريك و نايار امتريك در يِشبينى دبى ميانخين روزانه رودخانه كارون (مطالعه موردى: ايستخاه هيدرومترى ملاثانى)

\author{
مهدى علمىنزادى، سيدفرهاد موسوى * و خسرو حسينى' \\ (تاريخ دريافت:
}

جكيده

امروزه، بيثينى جريان رودخانهها از مباحث مهم در هيدرولوزى و منابع آب است كه مىتوان از نتايج الكوبندى جريان رودخانه در مديريت منابع

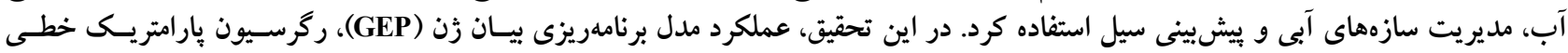

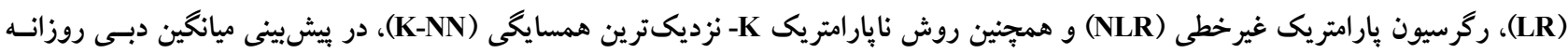

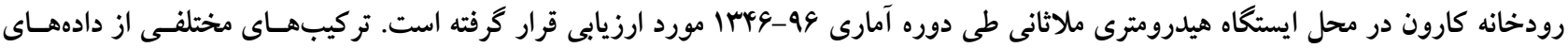

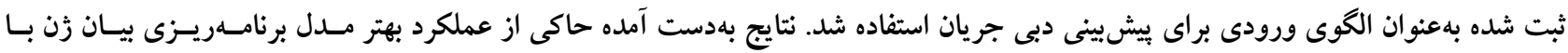

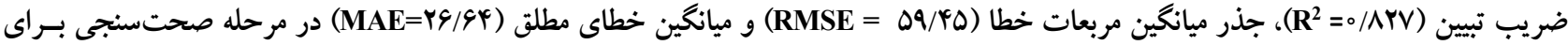

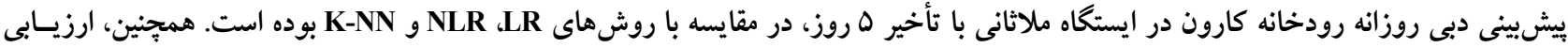

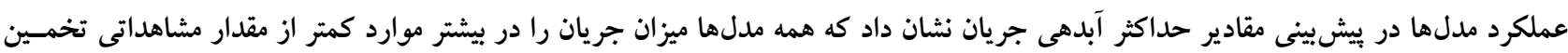

وازههاى كليدى: آبدهى رودخانه، برنامهريزى بيان زن، رگرسيون خطى و غيرخطى، K - نزديكترين همسايكى، كارون.

ا. گروه مهندسى آب و سازههاى هيدروليكى، دانشكده مهندسى عمران، دانشگاه سمنان

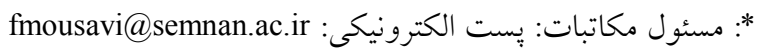


زمانى و همكاران (TQ) با استفاده از برنامـهريـزى بيـان زن،

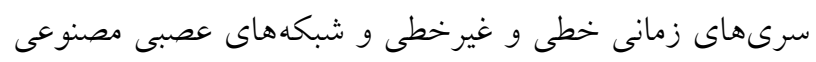
Artificial neural networks, ANN) روزانه ايستخاه ارمند روى رودخانه كارون كردهاند. نتايج نشـان

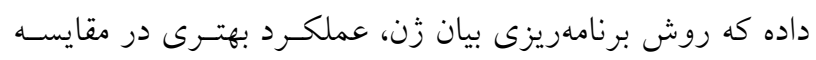

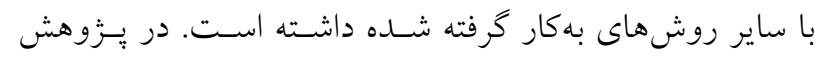

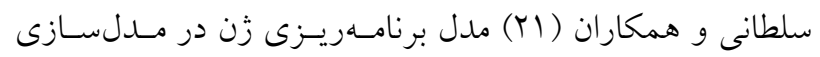

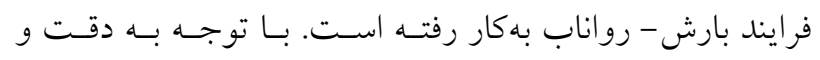

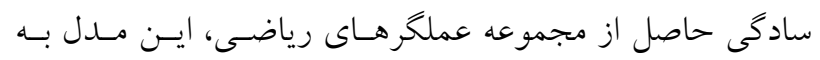

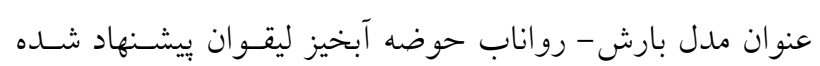

مدلهاى مبتنى بر ركرسيون نيـز از روشهـايى هستـند كـه

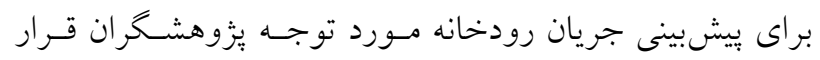

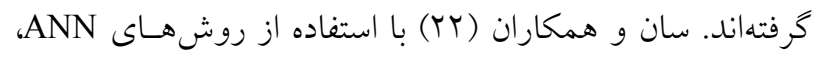

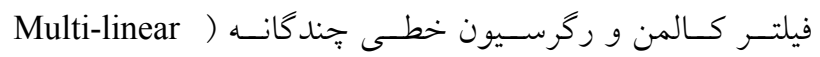

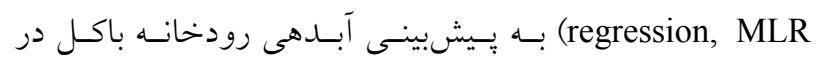

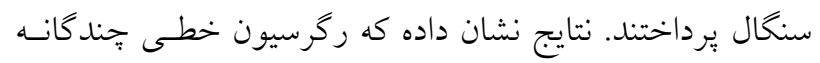
در كام زمانى كوتاهمدت عملكرد مناسبتـرى نسـبت بـه سـاير روش هاى مورد استفاده داشته است.

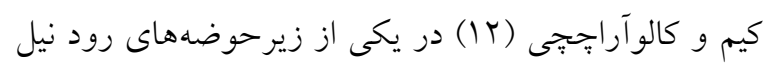

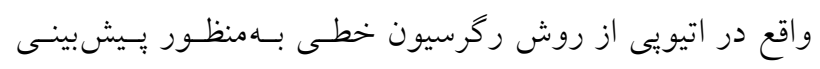

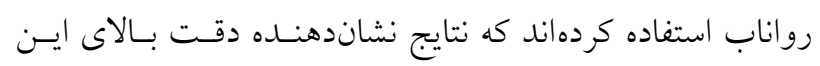

$$
\text { روش در بيشبينى رواناب بوده است. }
$$

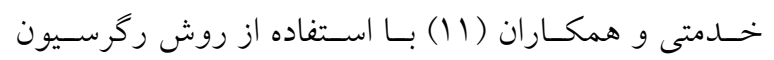

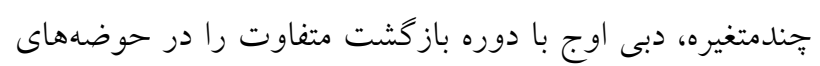
جنوب شرق ايران برآورد كردهاند.

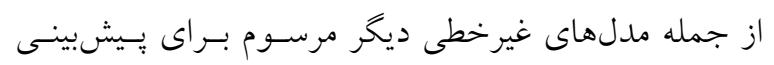

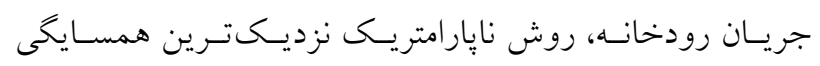
است كه همواره مـورد توجـه (K- nearest neighbor, K-NN)

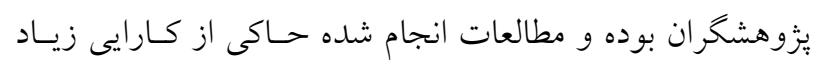

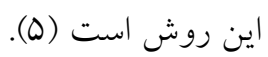

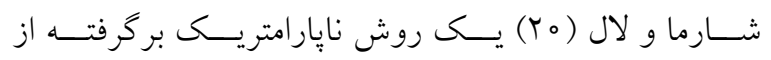

مدلهاى بـيشبينسى روانـاب مجموعـهاى از روشهـاى بسـيار

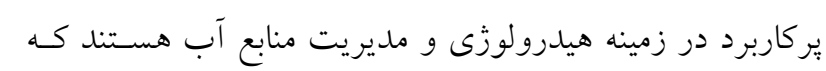

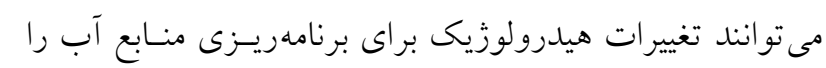

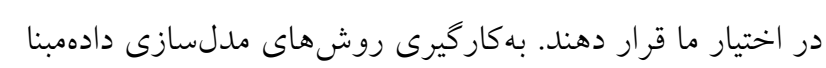

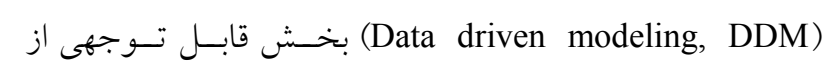

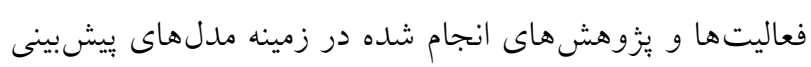

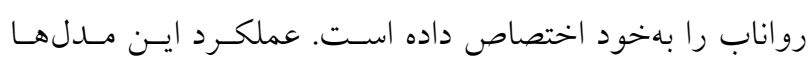

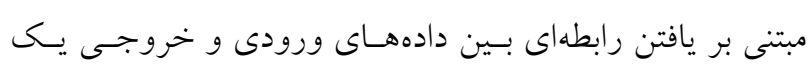

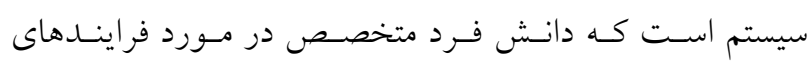

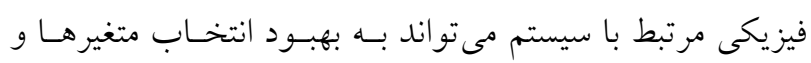

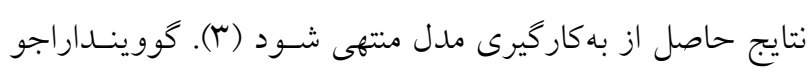

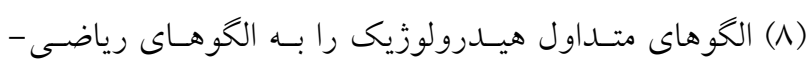

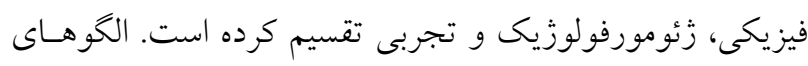

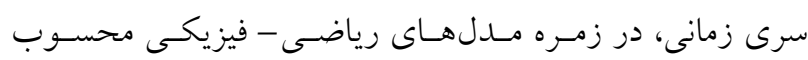

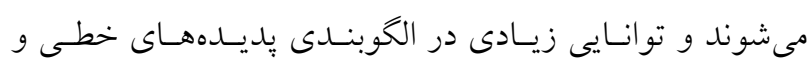

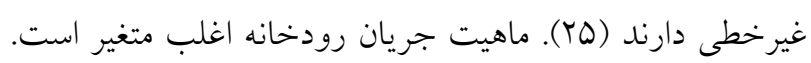

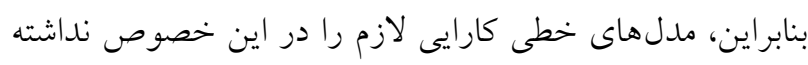

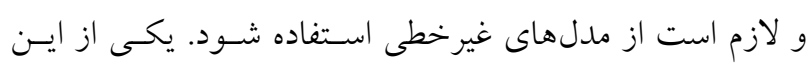

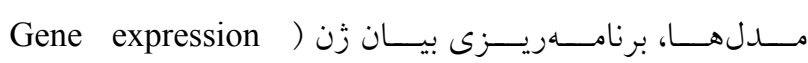
(programming, GEP

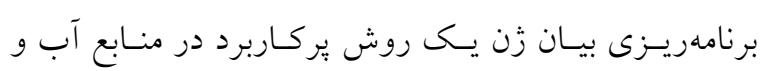

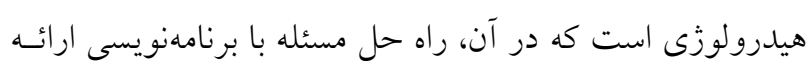

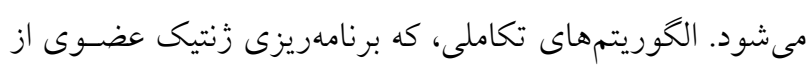

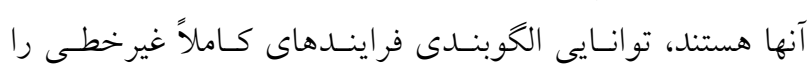

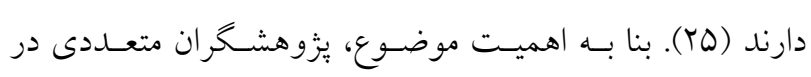

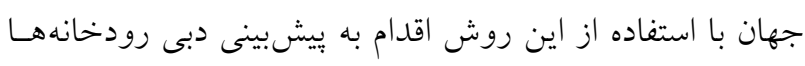

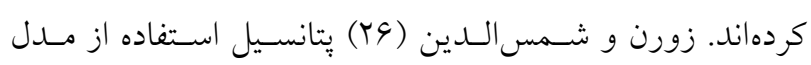

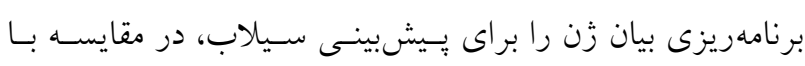
روش هاى معمــول تخمسين سـيلاب، در منطقـه او كلنـــ كشـور

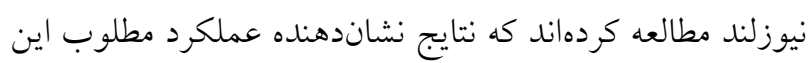
مدل بوده است. 


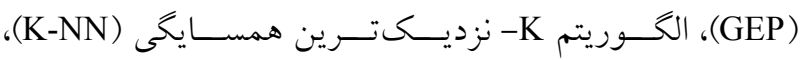
ركرسيونهاى خطى و غيرخطى و مقايسه نتايج آنها است.

\section{مواد و روشها}

منطقه مورد مطالعه و دادهها

رودخانه كارون، واقع در حوضه آبريز كارون بزرگ (شـكل ())، در جنوب غربى ايران، به طـول حسدود ه19 كيلـومتر، يكسى از طولانى ترين و ير آبترين رودخانه هاى ايران محسوب مئشسود.

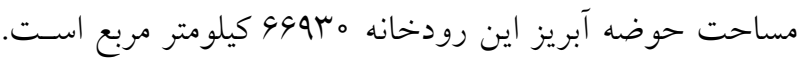

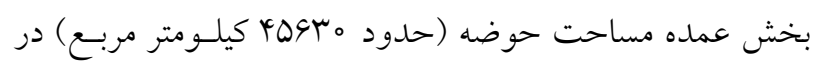

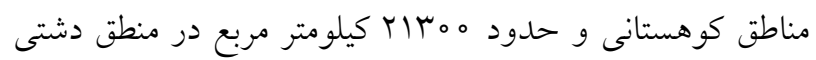
و كوهيايهاى واقع شده است (Y).

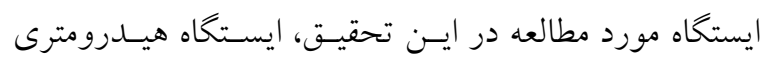

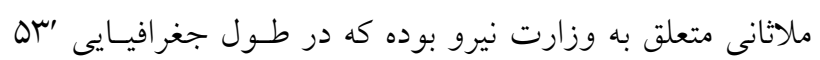

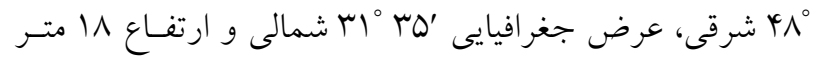

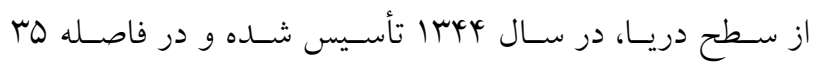
كيلومترى شمال شهر اهواز واقع شده است (شكل در (1). حوضـه

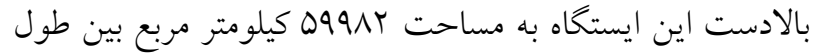

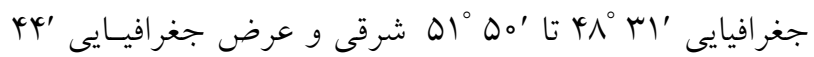

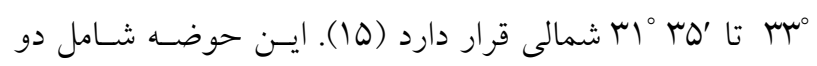

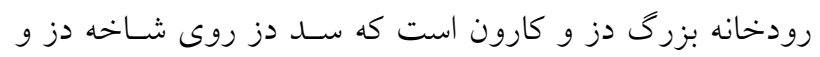

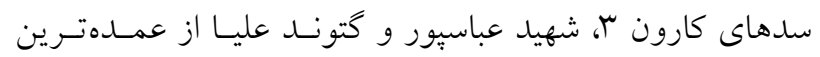

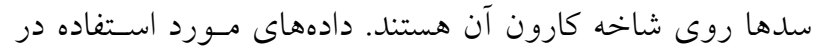

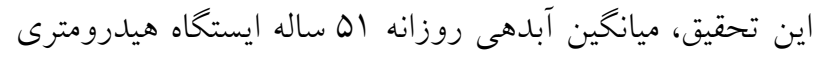

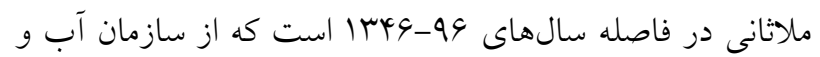
برق استان خوزستان بهدست آمدهاند.

\section{روند دادههاى سرى زمانى}

يارامترها و دادههاى هيدرولوزيك بايستى جنبه تصادفى داشـته و فاقد روند (Trend) باشند. درصورتى كه سرى زمانى دادههاى

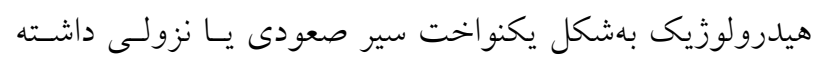

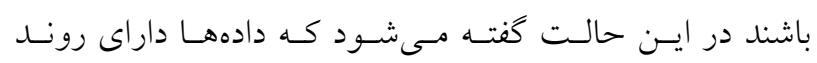

الكوريتم K-NN را براى شبيهسازى بارش روزانه ارائه دادهانـــ.

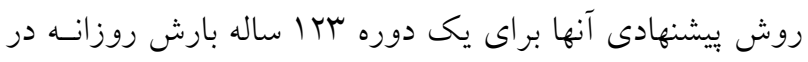

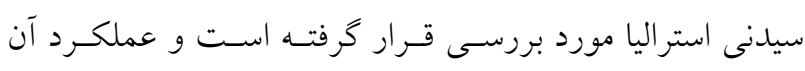

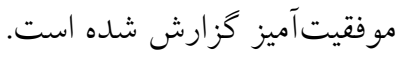

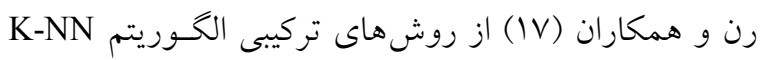
براى ييشبينى سـيلاب حوضـه كـدونغ (Gedong) در كشـور جين استفاده كردهاند. نتايج اين تحقيق نشان مىدهد كه اكوريتم

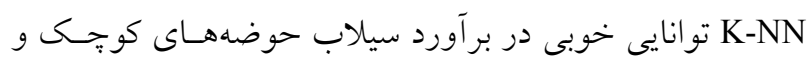
متوسط داشته است.

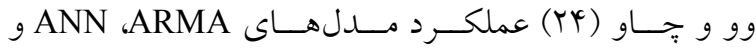
K-NN را در بيشبينى جريان ماهانه در جنندين رودخانه در كشـور

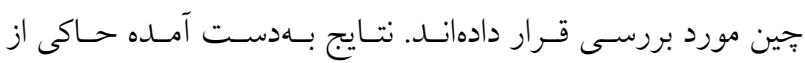
عملكرد قابل قبول K-NN در مقايسه با ساير روشها بوده است. در ايران نيز مطالعاتى در خصوص بهكارگيرى روش K-NN

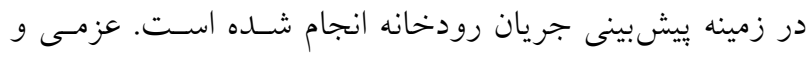

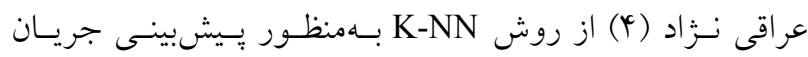

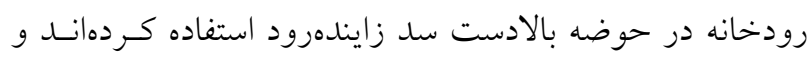
اين روش را براى سرىهاى تاريخى بلندمـــت مناسـبـ دانسـته

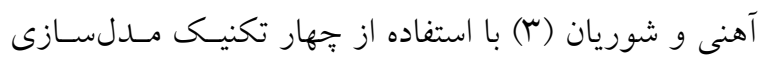

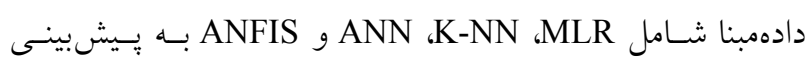

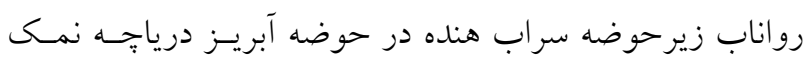

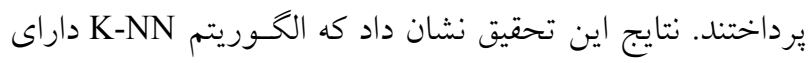

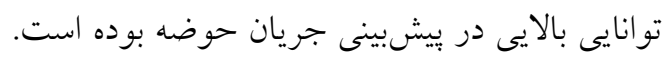

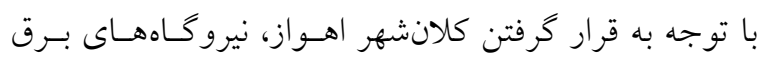

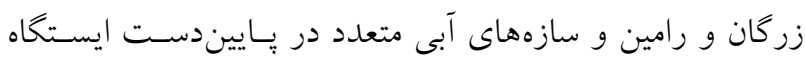

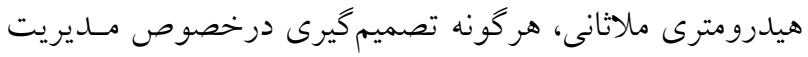

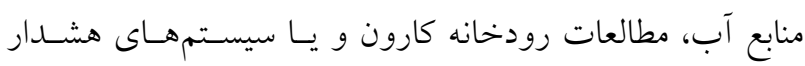
سيل در بِاييندست اين ايستخاه، نيازمند بيشبينى مناسب ميـزان

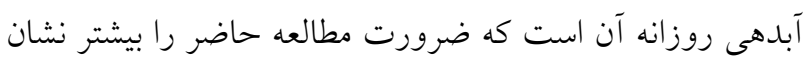

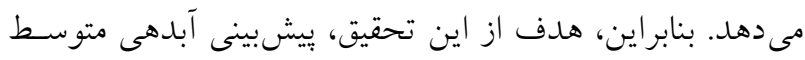

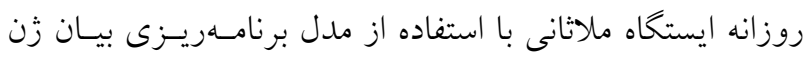




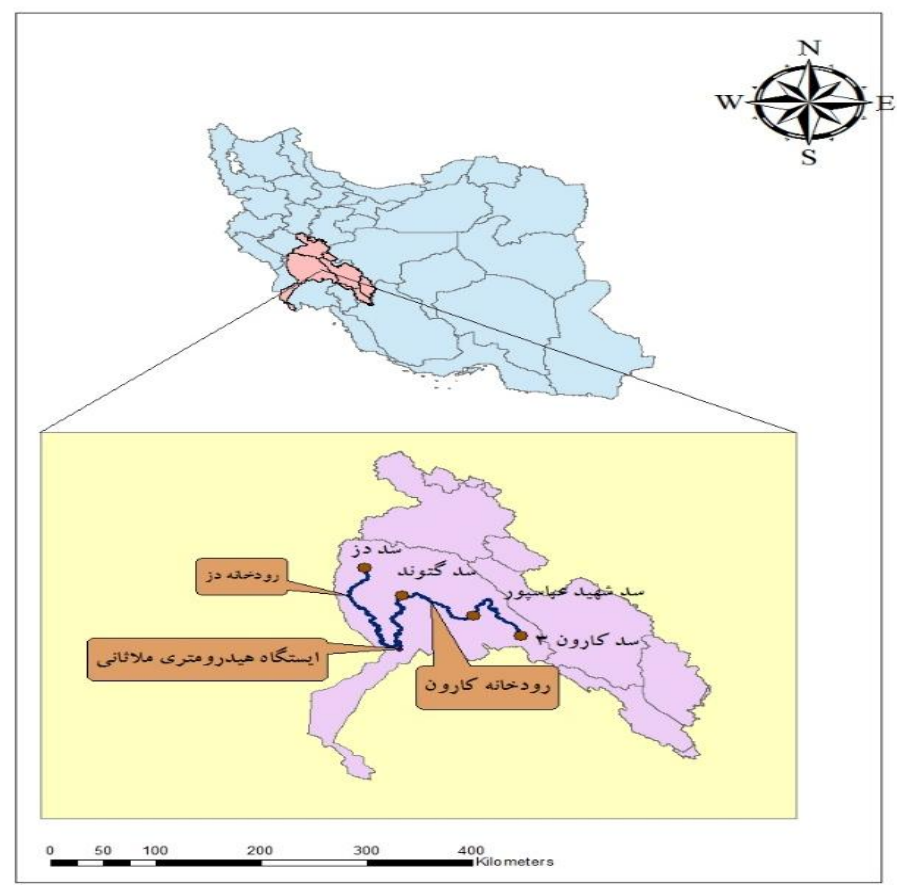

شكل ا. موقعيت حوضه كارون بزرگ، ايستخاه هيدرومترى ملاثانى و سدهاى بالادست آن

1/99+ و بزرگتر از 1/99- باشد، دادهها فاقد رونـــ بـوده و در

سطح اعتماد 90 درصد تصادفى اند (N).

آزمون سير تناوبى

فرمولبندى يك مدل رياضى و ارزيابى يك سرى زمانى توسط لرون

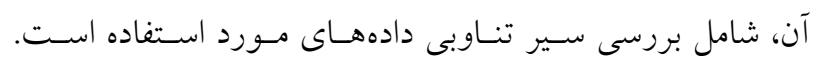
سرىهاى زمانى حاصل از برداشتهــاى طبيعى، بيشـتر نـوعى

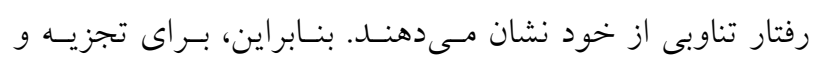

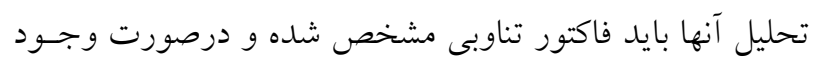

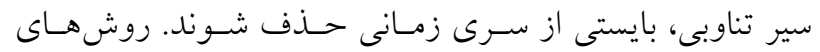
كوناكونى براى شناسايى سير تناوبى دادههـا وجــود دارد نظيـر:

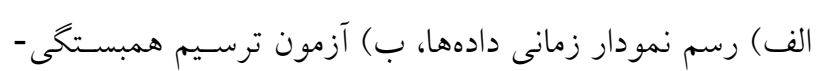

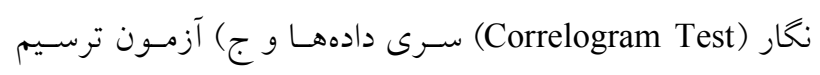

دورهنخار (I (1) (Periodogram Test)

$$
\text { آزمون كفايت دادهها }
$$

يكى از روشهاى آزمـودن كفايـت طـول دادههـاى سـرىهـاى دهـ
بــوده و ضـرورت دارد كـهـ رونـــ آنهـا برطـرف شـود. يكسى از راهكارهاى بررسى روند دادهها، استفاده از آزمـون مـن - كنـدال (Mann-Kendall) از سرى كه مستقل و داراى توزيع يكسان هستند گرفته شدهاند. اخر

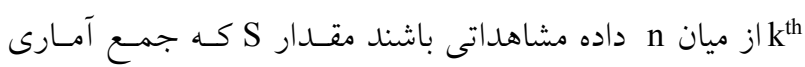
كندال نام دارد از رابطه إ حاصل مىشود: $\mathrm{S}=\sum_{\mathrm{K}=1}^{\mathrm{n}-1} \sum_{\mathrm{j}=\mathrm{k}+1}^{\mathrm{n}} \operatorname{sgn}\left(\mathrm{x}_{\mathrm{j}}-\mathrm{x}_{\mathrm{k}}\right)$ يكى ديخر از بارامترهاى آمارى مورد نياز آزمـون مـن - كنـدال، مقدار استاندارد Z (رابطه r) است: $Z=\left\{\begin{array}{l}(\mathrm{S}-1) / \sqrt{\mathrm{V}(\mathrm{S})} \text { for } \mathrm{S}>0 \\ 0 \text { for } \mathrm{S}=0 \\ (\mathrm{~S}+1) / \sqrt{\mathrm{V}(\mathrm{S})} \text { for } \mathrm{S}<0\end{array}\right.$

مقدار V(S) رابطه r از رابطه r حاصل مىشود: $V(S)=\frac{n(n-1)(2 n+5)}{18}$ ميزان Z در سطح ه درصد آزمون مىشود. اخر Z كوجــــــ از 
فرايند كام به كام حل يك مسئله با اسـتفاده از برنامسهريـزى

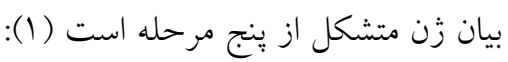

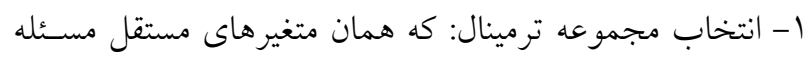

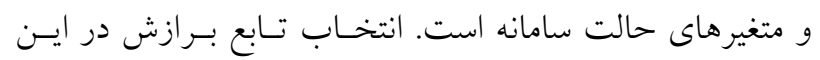

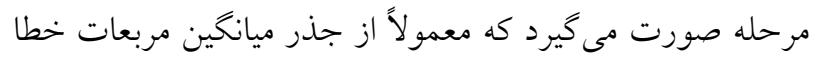
استفاده مىشود. (Root mean square error, RMSE)

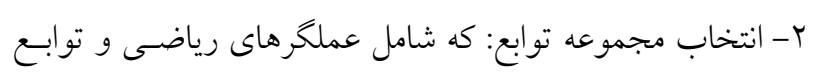

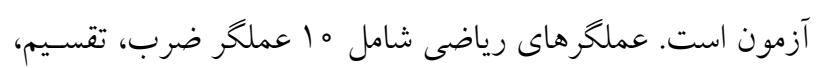

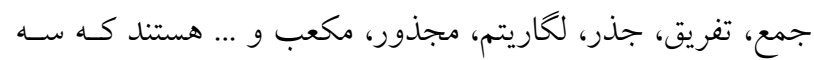

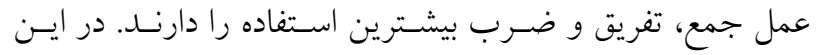
يُزوهش، از عملكرهاى ضرب، جمع و تفريق استفاده شده است.

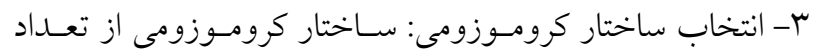
كروموزومها، اندازه سر (Head) و تعداد زنها تشكيل شده است.

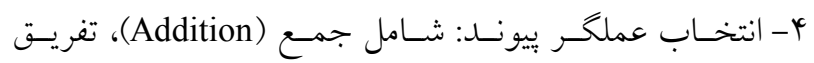
(Multiplication) و و تقسيم (Subtraction) هستند. ه- انتخاب عملكرهاى زنتيكى: شامل نرخ جهـش، نـرخ وارون

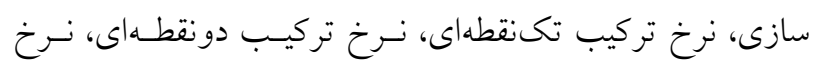

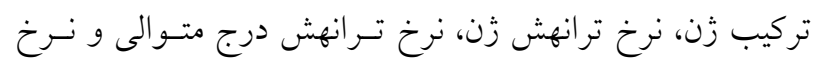
ترانهش درج ريشه.

\section{ركر سيون پِارامتريك رگر سيون خطى} روشهاى درونيابى در مهندسى آب قـدمت زيـادى داشـته و براى حل و مدلسازى يارامترهاى آن مورد استفاده قـرار گرفتـهـ

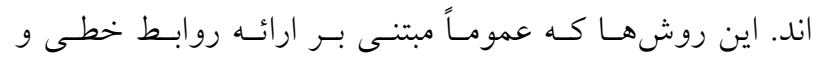

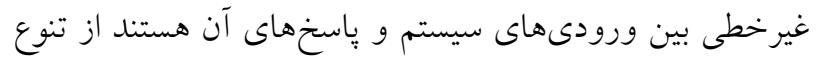
فراوانى برخوردارند. رخرسيون خطى (Linear regression, LR)

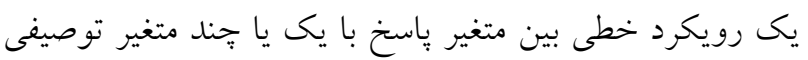

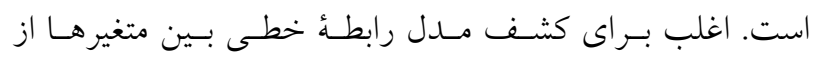

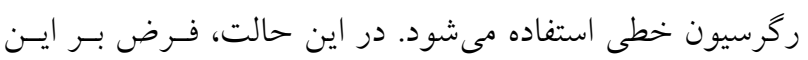

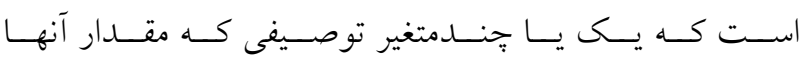

زمانى براى استفاده در مدلسـازى، اسـتفاده از ضـريب هرسـت است. اين ضريب بـراى سـنجش حافظـه.

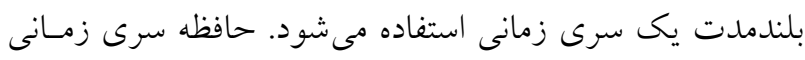

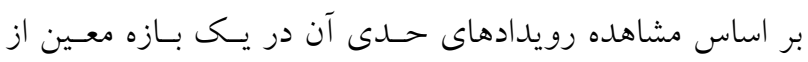

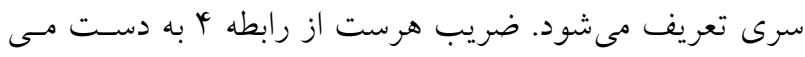
$\mathrm{K}=\frac{\log \frac{\mathrm{R}}{\sigma}}{\log \frac{\mathrm{N}}{2}}$

كه N تعداد داده در سرى زمانى و م انحراف معيار سرى است.

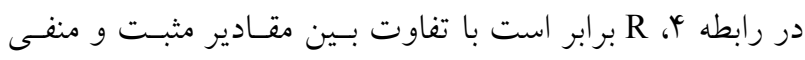

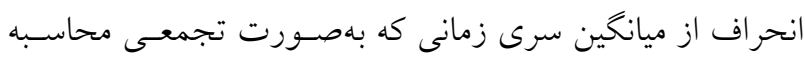

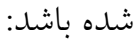

$\mathrm{R}=\mathrm{S}+-\mathrm{S}$

مقدار ضريب هرست برابر با ه/ه براى سرى زمانى نشاندهنــه

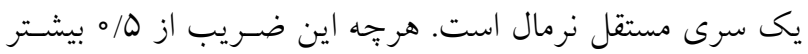
باشد، حافظه بلندمدت در سرى زمانى بيشتر است و نيازى براى طولانى كردن اطلاعات سرى زمانى نيست (10).

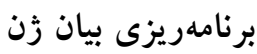

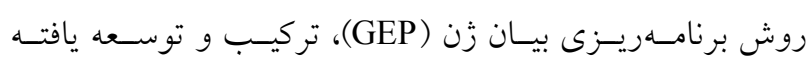

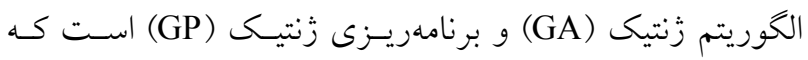

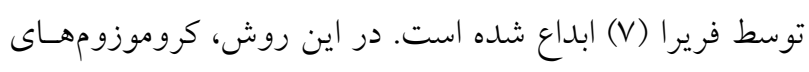

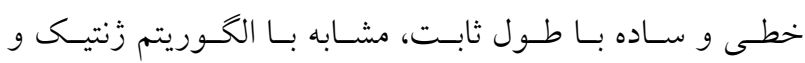

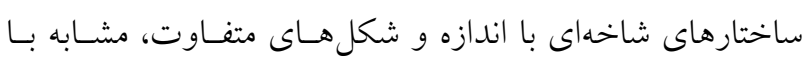
درختان تجزيه در برنامهريزى زنتيك، تركيب مى شـوند. مرحلـه

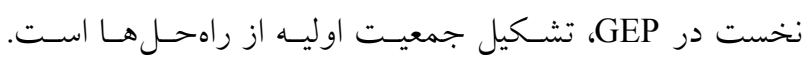

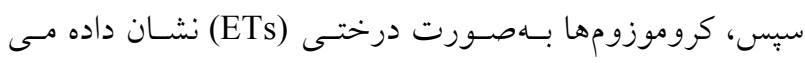

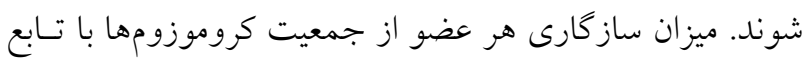

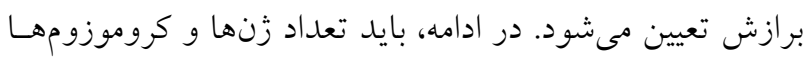

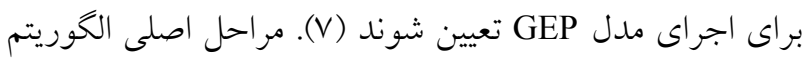
مدل برنامهريزى بيان زن در شكلهـاى ب و بـ نشـان داده شــده 


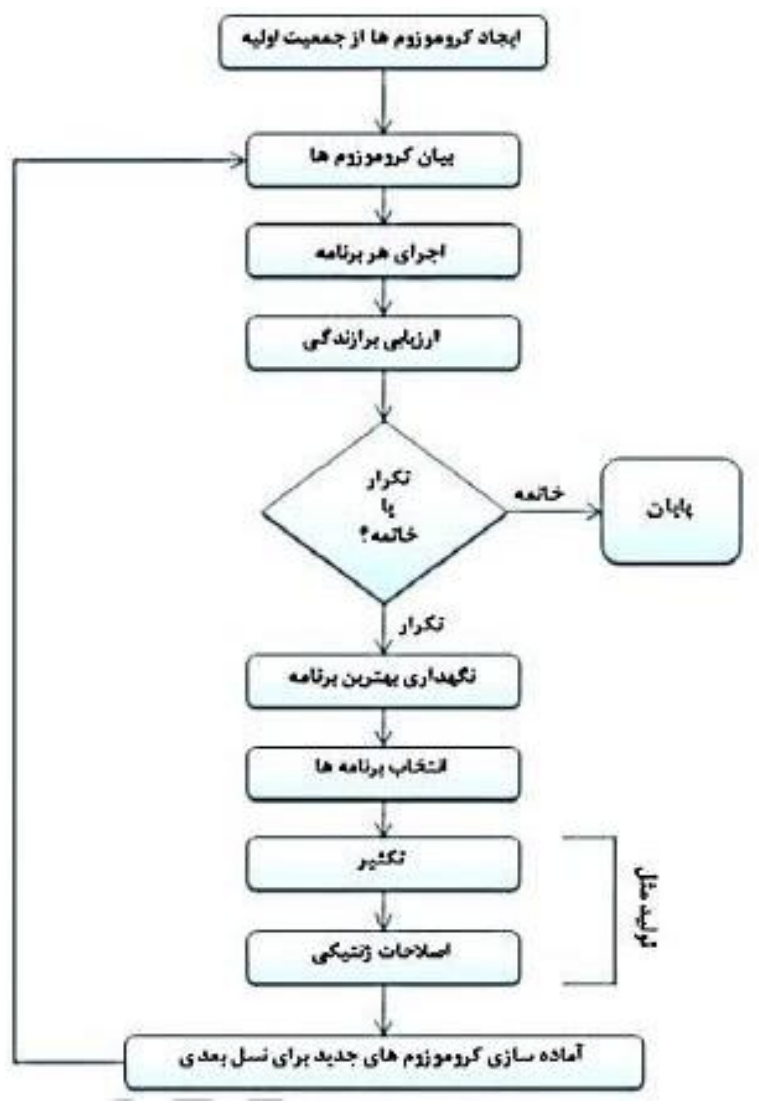

شكل r. الخوريتم برنامهريزى بيان زن (V)

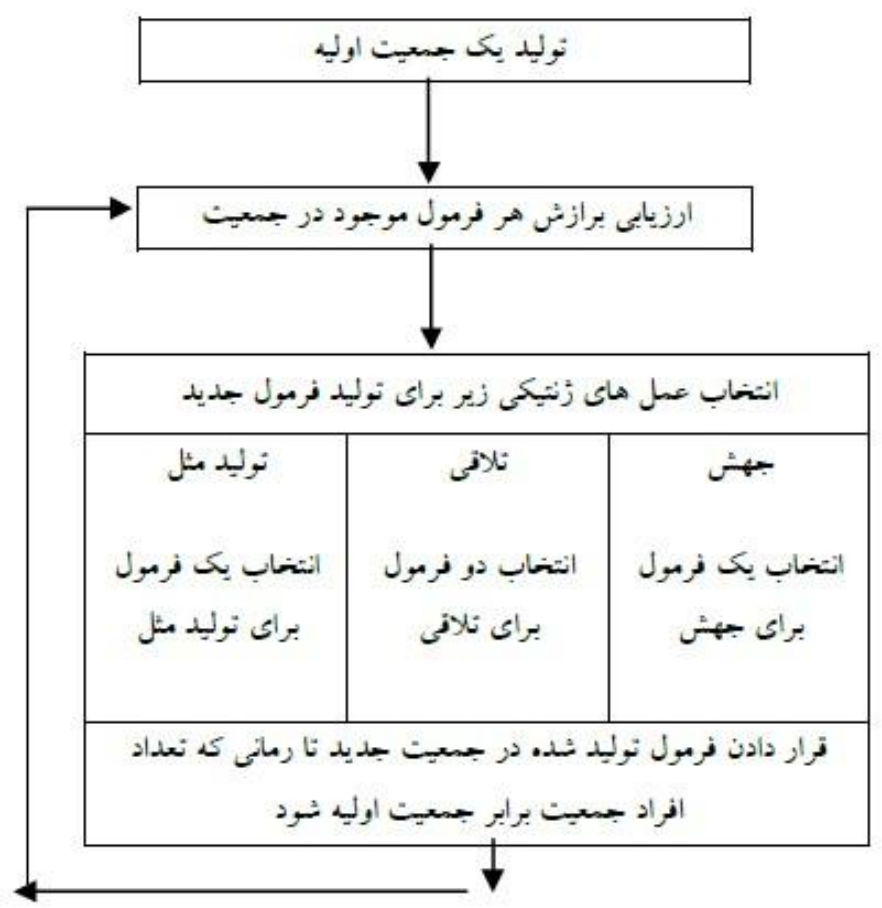

شكل r. مرورى بر شكل كلى اجراى برنامهريزى بيان زن (1) 
(دادههاى آموزشى) حداقل مى كند:

$c\left(y^{N P}\right)=\frac{\left.\sum_{i=0}^{n} y_{i}-y^{N P}\right)^{2} K(X i, X 0, b)}{N}$

در اين رابطه، متغير خروجى با yi و متغيرهاى ورودى بهصورت بردار Xi نشان داده شدهاند و X0 مشخص كننده نقطسه يرسـش بوده و از مجموعه دادههـاى آزمـون در فضـاى (Query point) ورودى انتخاب مىشود. متغيرهاى ورودى را مسىتـوان بـارش،

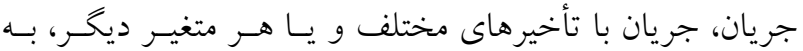
طورى كه تركيبى از اين متغيرها در يك يا تهند ايستخاه باشــد،

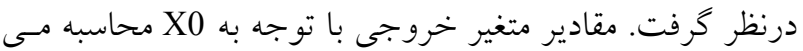

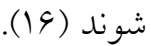

مشابه DN، مجموعه ديخرى تحت عنـوان دادههـاى آزمـون

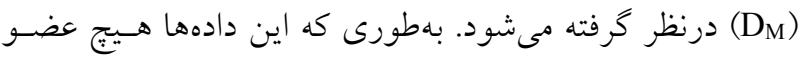

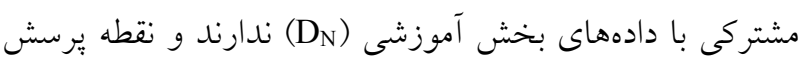

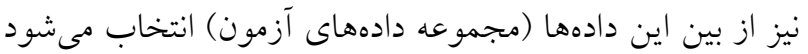

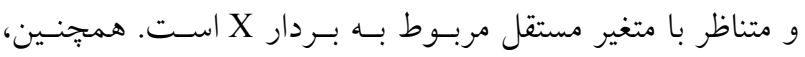

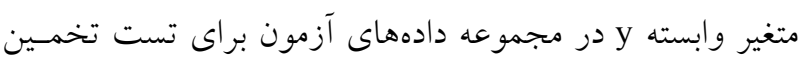

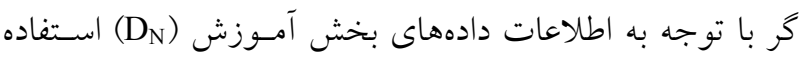
مىشود.

تابع K نيز معرف وزن يا تابع كرنل اسـت كـه مقــدار آن بـاــا توجه به فاصله اقليدسى هـر نقطه در بخـش آمـوزش از نقطه. يرسش در بخش آزمون طبق رابطه م بهدست مى آيد: $\mathrm{K}\left(\mathrm{X}_{\mathrm{i}}, \mathrm{X}_{0}, \mathrm{~b}\right)=\left\{\begin{array}{lll}1 & \text { if } & \mathrm{X}_{\mathrm{i}}-\mathrm{X}_{0} \leq \mathrm{b} \\ 0 & \text { if } & \mathrm{X}_{\mathrm{i}}-\mathrm{X}_{0}>\mathrm{b}\end{array}\right.$

در اين رابطـه، || شعاع همسايكى است. كمينه كردن رابطه ^ با توجـهـ بـه مقــدار

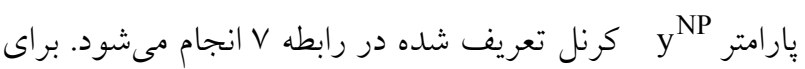
تخمين yn از رابطه 9 استفاده مىشود:

$\mathrm{y}_{\text {Pred }}^{\mathrm{nn}}=\frac{\sum_{\mathrm{i} \in \mathrm{I}_{\mathrm{nn}}} \mathrm{y}_{\mathrm{i}}}{\left|\mathrm{I}_{\mathrm{nn}}\right|}$

كه در آن Inn مجموعهاى است كه عضـوهاى آن، آن تعـداد از

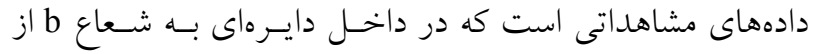

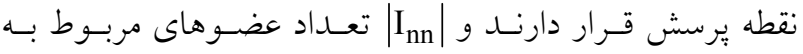

مستقل از بقيه متغيرها يا تحت كنترل محقق است، مسىتوانــ در

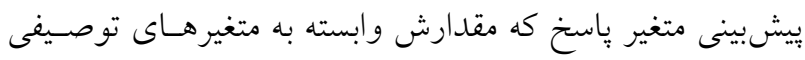
و تحت كنترل محقق نيست، مـؤثر باشــــ تفـاوت ركرسـيون و

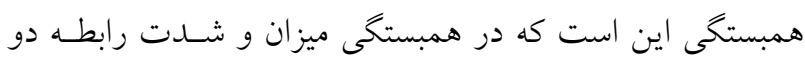

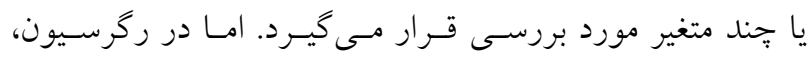

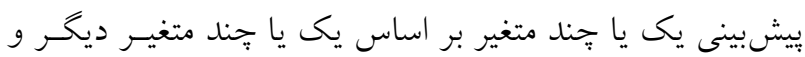

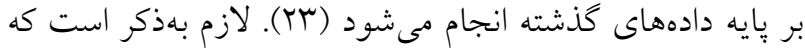

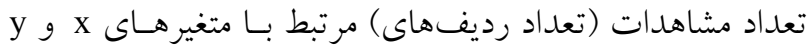
بايد با هم برابر باشند. بيشفرض رابطه بين X و y بهـصورت

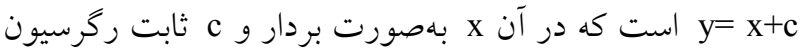

\section{رگر سيون غيرخطى}

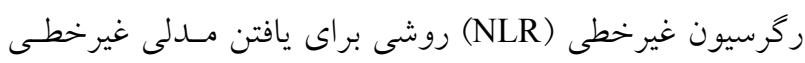

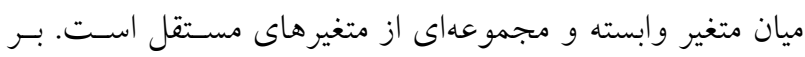

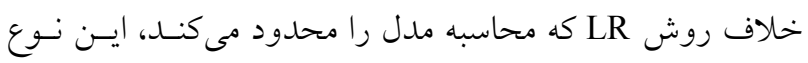

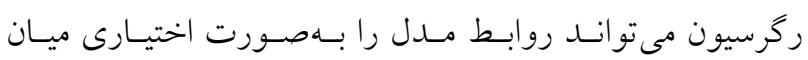

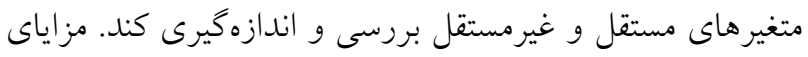

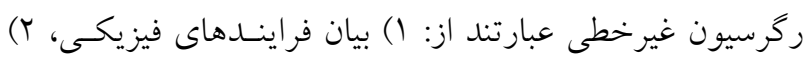

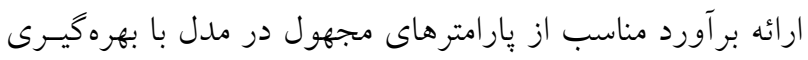

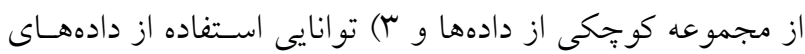
كمى و كيفى (T) (T).

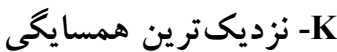

روش K نزديكترين همسايخى (K-NN) يكسى از مهـمتـرين و توسعهيافته ترين رويكردهاى نايارامتريكى است كه در بسيارى از

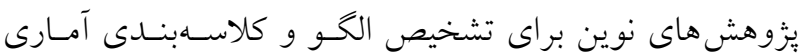

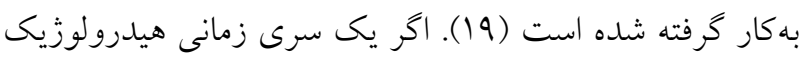

$\mathrm{D}_{\mathrm{N}}=\left\{\{\mathrm{yi}, \mathrm{xi}\} \in \mathrm{R}_{+\times}^{1} \mathrm{R}_{+,}^{1} \mathrm{i}=1, \ldots, \mathrm{N}\right\}$

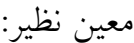

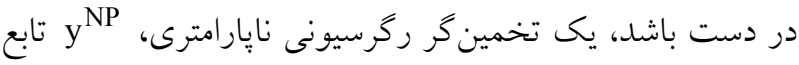
هزينه (Cost function) زير را روى بردار سرىهاى زمـانى لهرئ 


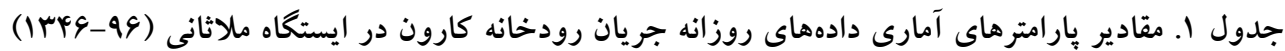

\begin{tabular}{|c|c|c|c|c|c|c|c|}
\hline $\begin{array}{l}\text { جولكى } \\
\left(\mathrm{m}^{3} / \mathrm{s}\right)\end{array}$ & ضريب تغييرات & $\begin{array}{c}\text { انحر اف معيار } \\
\left(\mathrm{m}^{3} / \mathrm{s}\right)\end{array}$ & حداقل & $\begin{array}{l}\text { حلاكثر } \\
\left(\mathrm{m}^{3} / \mathrm{s}\right)\end{array}$ & $\begin{array}{l}\text { ميانخين } \\
\left(\mathrm{m}^{3} / \mathrm{s}\right)\end{array}$ & تعداد داده & نام دوره \\
\hline$r / 90$ & ०/AG & $\Delta \wedge V / A Y$ & Kr/G & GYGT & $9 \vee 9 / 11$ & 14900 & آموزش \\
\hline$r / 90$ &.$/ 9 r$ & $r V T / q r$ & $\Lambda 9$ & 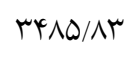 & $\xi \circ r / V \Lambda$ & מVTr & صحتسنجى \\
\hline
\end{tabular}

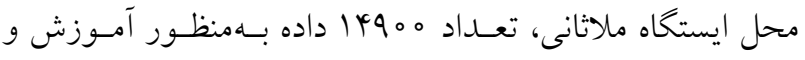

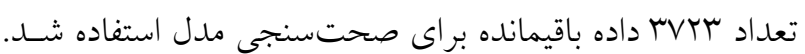

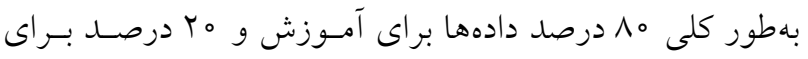
تست درنظر كرفته شده است. يُارامترهـاى آمـارى دبسى روزانـه ايستخاه ملاثانى در جدول ا ارائه شدهاند. مطابق نتايج جدول ا، اكر جهه حداكثر دبى در دوره آموزش

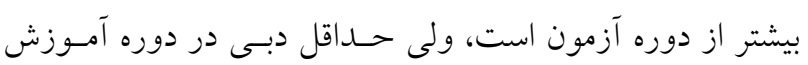

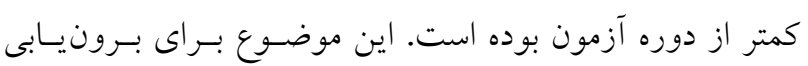

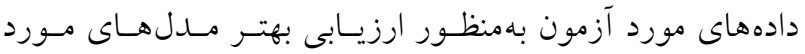
استفاده در اين تحقيق داراى اهميت است (rا).

\section{نتيجه بررسى روند دادههاى سرى زمانى}

نتيجــه بررسـى رونـــ دادههـاى ميـانخين دبسى روزانـه ايستخاه

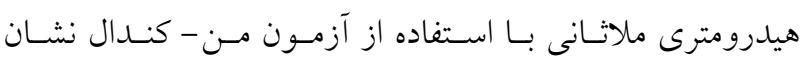
مىدهد كه دادههاى استفاده شده در اين تحقيق در سطح اعتمـاد 90 درصد فاقد روند بوده و تصادفى هستند (شكل \&)

$$
\text { نتيجه آزمون سير تناوبى }
$$
همان كونه كه شكل ه نشان مى دهل، سرى زمانى مـورد اسـتفاده در اين تحقيق فاقد سير تناوبى بوده و قابليت لازم براى اسـتفاده

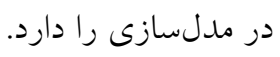

\section{نتيجه آزمون كفايت دادهها}

مقدار ضريب هرست براى دادههاى روزانه ايستخاه هيـدرومترى

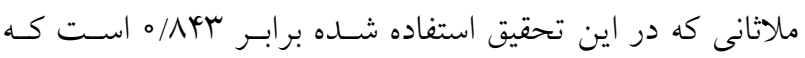

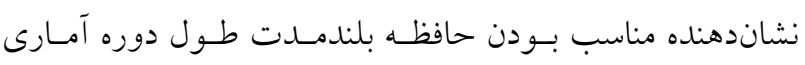

مجموعه Inn I I است. يعنى:

$\left|\mathrm{I}_{\mathrm{nn}}\right|\left\{\mathrm{i}: \mathrm{X}_{\mathrm{i}}-\mathrm{X}_{0} \leq \mathrm{b}\right\}$

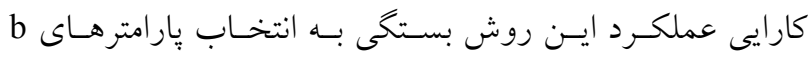
(شعاع همسايخى) و I (تعداد تأخيرهـا در پيارامترهـاى ورودى)

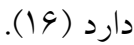

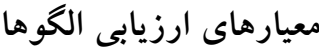

نمايه هاى ضريب تبيين (Determination coefficient, R²) جذر ميـانخين مربعـات خطـا (RMSE) و متوسـط خططـاى مطلـق براى ارزيـابى الكوهـاى مـورد (Mean absolute error, MAE) مطالعـه در ايسن تحقيـق اسـتفاده شـدهانــ (روابـط ال تـا با). درصورتى كه مقدار ضريب تبيين زياد و ضرايب خطا كم باشـد مىتوان نتايج دقيقتر و قابل اعتمادترى بهدست آورد:

$$
\mathrm{R}^{2}=1-\frac{\sum_{\mathrm{i}=1}^{\mathrm{n}}\left(\mathrm{Q}_{\mathrm{O}}-\mathrm{Q}_{\mathrm{P}}\right)^{2}}{\sum_{\mathrm{i}=1}^{\mathrm{n}}\left(\mathrm{Q}_{\mathrm{O}}-\overline{\mathrm{Q}}\right)^{2}}
$$

$\operatorname{RMSE}=\sqrt{\frac{\sum_{\mathrm{i}=1}^{\mathrm{n}}\left(\mathrm{Q}_{\mathrm{O}}-\mathrm{Q}_{\mathrm{P}}\right)^{2}}{\mathrm{n}}}$

$$
\mathrm{MAE}=\frac{\sum_{\mathrm{i}=1}^{\mathrm{n}}\left|\mathrm{Q}_{\mathrm{O}}-\mathrm{Q}_{\mathrm{P}}\right|}{\mathrm{n}}
$$

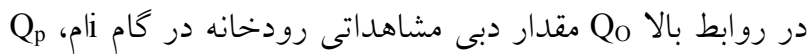
Q مقدار دبى بيشبينى شده در همان زمان، n تعـداد دادههـا و ميانكين مقادير دبى مشاهداتى است.

\section{نتايج و بحث}

در اين مطالعه، از دادههاى ميانخين دبى روزانه اله ساله ايستخاه هيدرومترى ملاثانى در سالهاى 99-94 إس استفاده شده اسـت. از مجموع سبع إ داده متوسط دبى روزانه رودخانـه كـارون در 


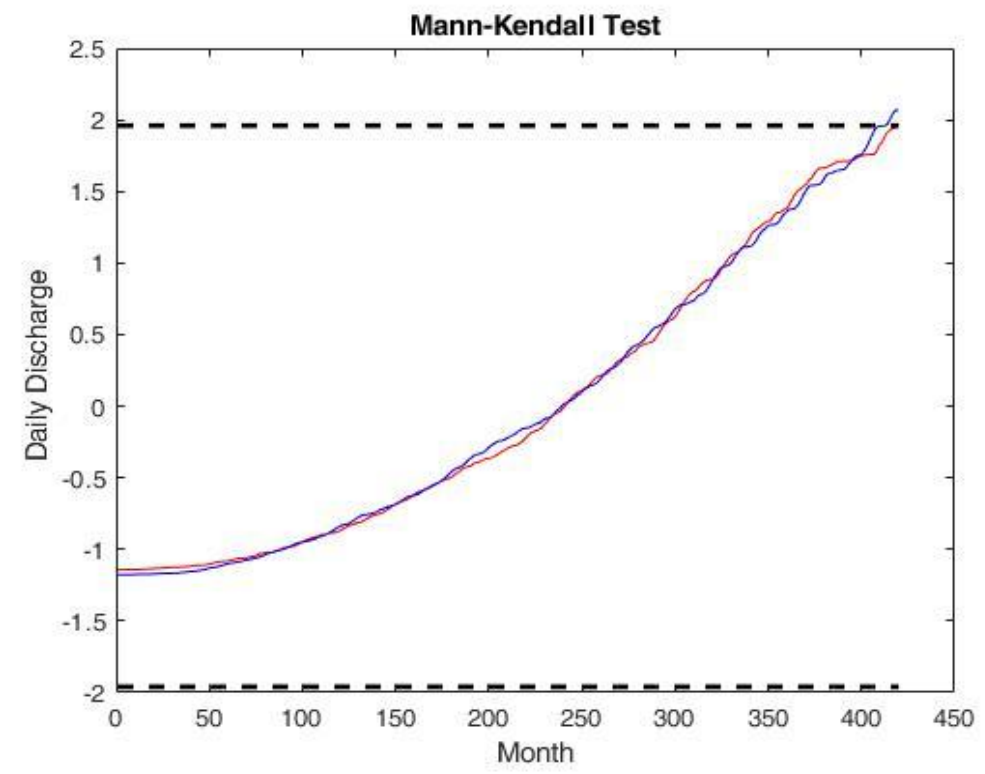

شكل ؟. نتايج آزمون من-كندال دادههاى ميانگين دبى روزانه ايستخاه ملاثانى

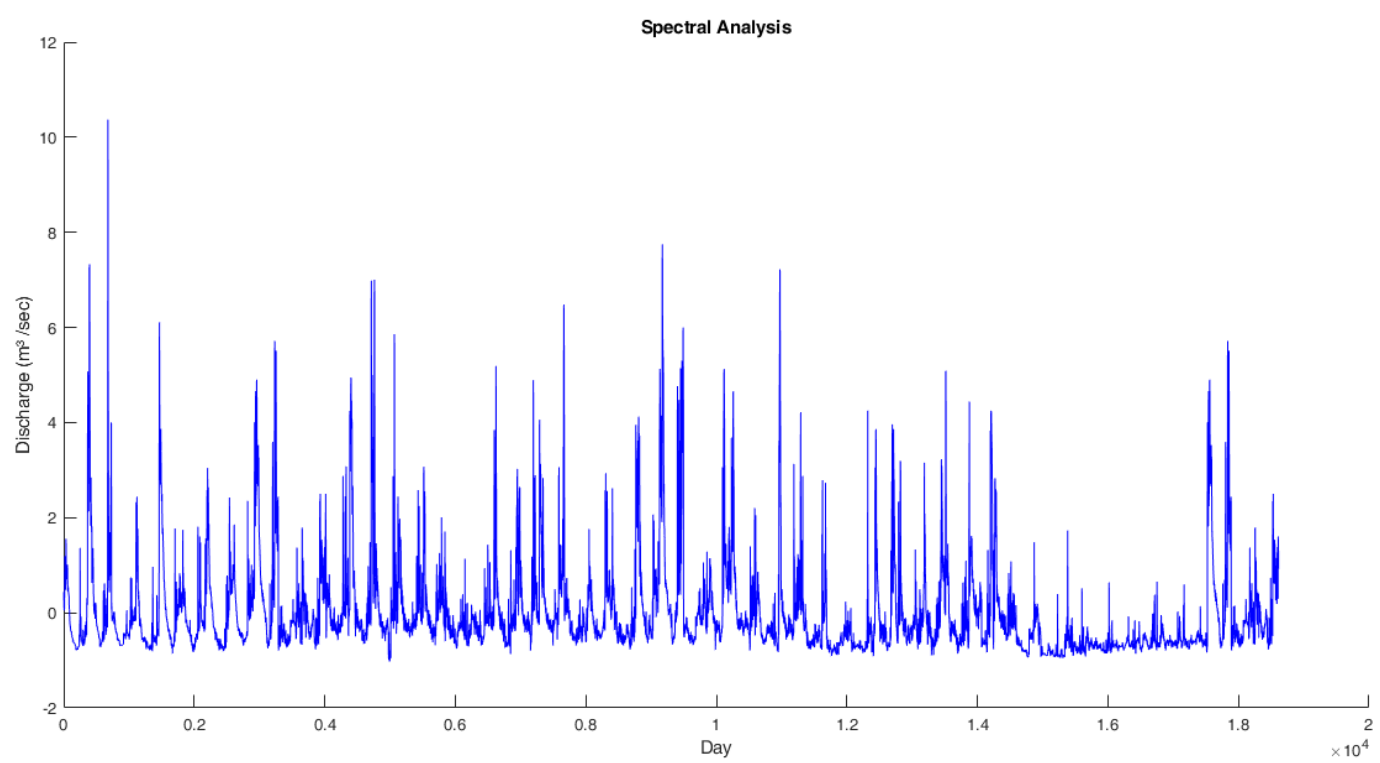

شكل ه. سير تناوبى دادههاى ميانگين دبى روزانه در ايستخاه هيدرومترى ملاثانى

يبشبينى دبى امروز مد نظر بوده اسـت فقـط از دادههـاى دبسى سرى زمانى است (شكل 9).

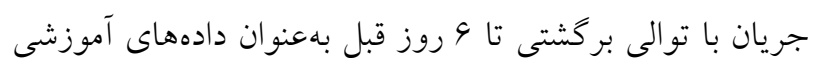

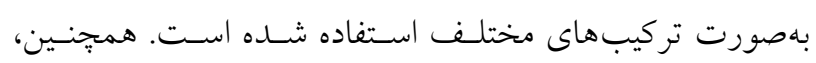
نتايج مدلسازى برنامهريزى بيان زن

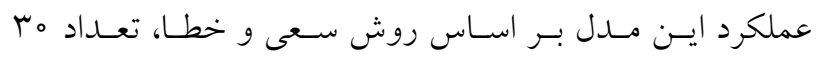
در مدل برنامهريزى بيان زن، انتخاب جمعيـت اوليـه كـه همـان

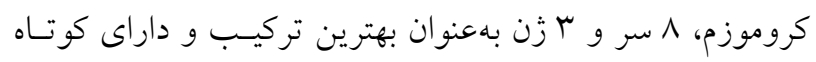

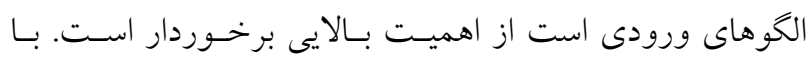

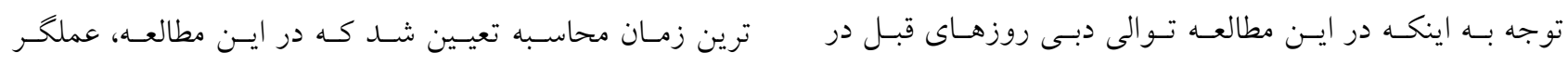




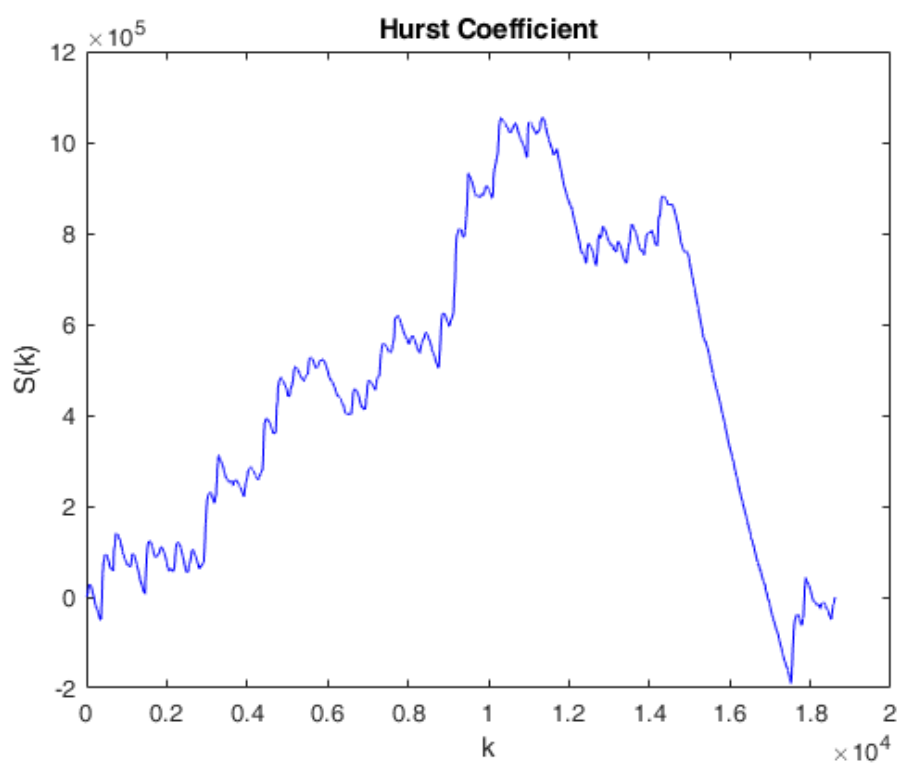

شكل 9. نتايج آزمون هرست دادههاى ميانگين دبى روزانه در ايستخاه ملاثانى

جدول r. تحليل آمارى نتايج الكوهاى مدل برنامهريزى بيان زُن براى بيشبينى ميانگين دبى روزانه در ايستخاه ملاثانى

\begin{tabular}{|c|c|c|c|c|c|c|c|}
\hline \multicolumn{3}{|c|}{ مرحله صحتسنجى } & \multicolumn{3}{|c|}{ مرحله آموزش } & \multirow[t]{2}{*}{ الكوى ورودى روزانه } & \multirow{2}{*}{ شــماره } \\
\hline RMSE & MAE & $\mathrm{R}^{2}$ & RMSE & MAE & $\mathrm{R}^{2}$ & & \\
\hline $119 / 01$ & KT/lG & $0 / \wedge 01$ & $\mid r Y / 00$ & $Y V / \circ Y^{k}$ & $\circ / V \wedge 9$ & $\mathrm{Q}(\mathrm{t})=\mathrm{f}\{\mathrm{Q}(\mathrm{t}-1)\}$ & 1 \\
\hline$\wedge \Delta / 11$ & $r N / Y Q$ & $\circ / \Lambda \circ r^{2}$ & $110 / \mathrm{A}$ & $\varphi \circ / \mu$ & $\circ / \mathrm{V} 91$ & $\mathrm{Q}(\mathrm{t})=\mathrm{f}\{\mathrm{Q}(\mathrm{t}-1), \mathrm{Q}(\mathrm{t}-2)\}$ & r \\
\hline $9 V / 9 T$ & $r \Delta / r \Delta$ & $\circ / \wedge / \circ$ & $11 \mathrm{r} / \mathrm{Q}$ & $4 \circ / \circ 9$ & $\circ / \mathrm{V} 91$ & $\mathrm{Q}(\mathrm{t})=\mathrm{f}\{\mathrm{Q}(\mathrm{t}-1), \mathrm{Q}(\mathrm{t}-2), \mathrm{Q}(\mathrm{t}-3)\}$ & r \\
\hline $94 / 10$ & $\mathrm{~m} / \mathrm{gV}$ & $\circ / \Lambda \mid F$ & $90 / \mathrm{VI}$ & $\mathrm{mq/gl}$ & $0 / \wedge \circ 1$ & $\mathrm{Q}(\mathrm{t})=\mathrm{f}\{\mathrm{Q}(\mathrm{t}-1), \mathrm{Q}(\mathrm{t}-2), \mathrm{Q}(\mathrm{t}-3), \mathrm{Q}(\mathrm{t}-4)\}$ & c \\
\hline $09 / 40$ & TS/94 & O/ATV & $V A / T r$ & TV/TY & $\circ / \Lambda \mid Y^{k}$ & $\mathrm{Q}(\mathrm{t})=\mathrm{f}\{\mathrm{Q}(\mathrm{t}-1), \mathrm{Q}(\mathrm{t}-2), \mathrm{Q}(\mathrm{t}-3), \mathrm{Q}(\mathrm{t}-4), \mathrm{Q}(\mathrm{t}-5)\}$ & 0 \\
\hline MN/OT & $\Delta 9 / 41$ & $\circ / \mathrm{QA \Lambda}$ & $149 / \mu \mathrm{V}$ & GY/Ar & $\circ / \mathrm{V} / 1$ & $\mathrm{Q}(\mathrm{t})=\mathrm{f}\{\mathrm{Q}(\mathrm{t}-1), \mathrm{Q}(\mathrm{t}-2), \mathrm{Q}(\mathrm{t}-3), \mathrm{Q}(\mathrm{t}-4), \mathrm{Q}(\mathrm{t}-5), \mathrm{Q}(\mathrm{t}-6)\}$ & 4 \\
\hline
\end{tabular}

حاصل از بهترين مدل برنامهريزى بيـان زن بــراى الخـوى ه در

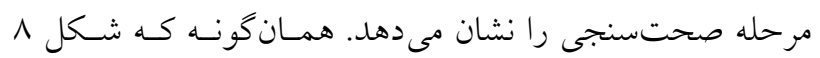

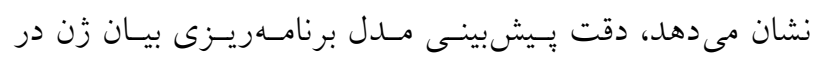
ييشبينى دبىهاى كمتر جريان، بهتر از دبىهاى بزرگتر جريـان

$$
\text { بوده است. }
$$

\section{نتايج مدلسازى رگرسيون خطى و غيرخطى} مطابق جدولهاى بَ و أ، بهازاى الكوهاى وروديى مختلف، بهتـرين عملكرد هر دو روش ركرسـيون خطى و غيرخطى در يسيشينسى جريان روزانه ايستخاه ملاثانى در الكوى شـماره هـ بـوده اسـت. بــر
جمع بهترين عملكرد را ارائه داد. در اين مطالعه، معيار توقف بر اساس ميزان جمعيت توليد شـده (Generation Number) برابـر ما تعيين شده است. نرم|فزار مورد استفاده در ايسن تحقيـق، GeneXproTools 5.0

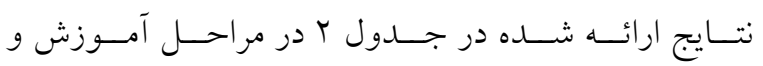

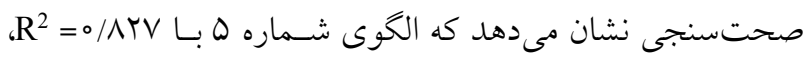

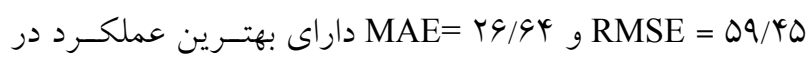
مرحله صحتسنجى بوده كه بهعنوان بهتـرين الخـو بــراى مـــل برنامسهريـزى بيـان زن انتخــاب شـــه اسـت. شـكل V نمــودار ير اكندكى و شكل ^ نمودار مقادير مشاهداتى و بيشبينى شـده 


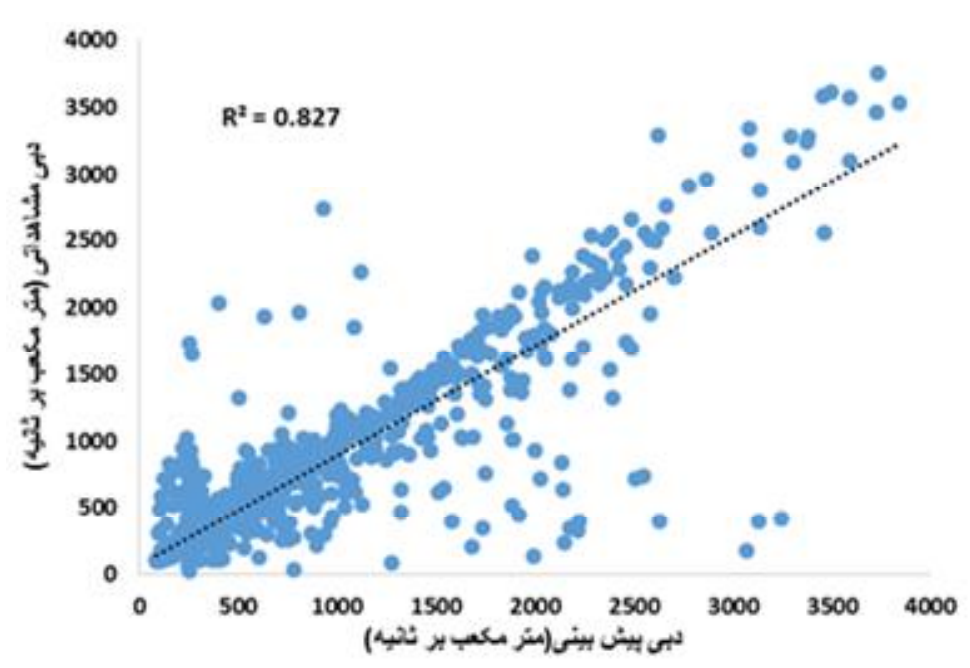

شكل V. نمودار براكندگى مقادير مشاهداتى و بيشبينى شده دبى روزانه ايستخاه ملاثانى با استفاده از

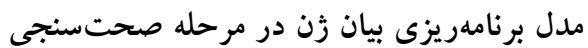

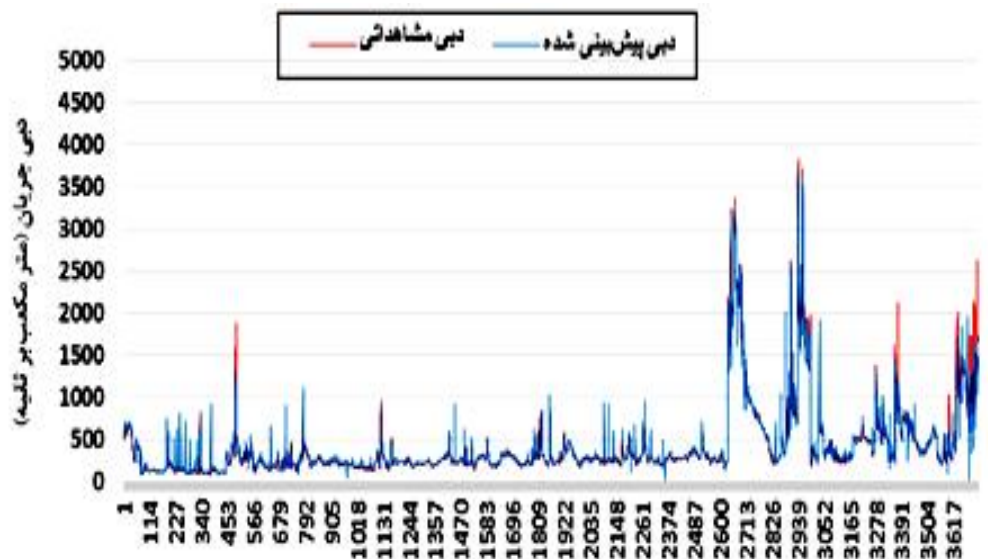

נؤ

شكل ^ـ مقادير مشاهداتى و يِيشبينى شده دبى روزانه ايستخاه ملاثانى با استفاده از مدل

برنامهريزى بيان زن در مرحله صحتسنجى (رنكى در نسخه الكترونيكى)

جدول r. تحليل آمارى رگرسيون خطى براى الخوهاى مختلف ورودى ميانگين دبى روزانه در ايستخاه ملاثانى

\begin{tabular}{|c|c|c|c|c|c|c|c|}
\hline \multicolumn{3}{|c|}{ مرحله صحتسنجى } & \multicolumn{3}{|c|}{ مرحله آموزش } & \multirow{2}{*}{ الكوى ورودى روزانه } & \multirow{2}{*}{ شماره } \\
\hline RMSE & MAE & $\mathrm{R}^{2}$ & RMSE & MAE & $\mathrm{R}^{2}$ & & \\
\hline 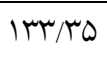 & $9 Y / 1 \Lambda$ & $\circ / V M Y$ & GN/MT & $V V / Y q$ & $\circ / Y_{0}$ & $\mathrm{Q}(\mathrm{t})=\mathrm{f}\{\mathrm{Q}(\mathrm{t}-1)\}$ & 1 \\
\hline $1 r q / 49$ & $90 / 19$ & $\circ / V \mu V$ & $9 Y / 11$ & $V 1 / \circ 0$ & $\circ / \mathrm{N} \Delta$ & $\mathrm{Q}(\mathrm{t})=\mathrm{f}\{\mathrm{Q}(\mathrm{t}-1), \mathrm{Q}(\mathrm{t}-2)\}$ & r \\
\hline $109 / 14$ & $\dot{\varphi} \wedge / \wedge r$ & $\circ / V 99$ & QN/TY & $99 / 9 V$ & o/var & $\mathrm{Q}(\mathrm{t})=\mathrm{f}\{\mathrm{Q}(\mathrm{t}-1), \mathrm{Q}(\mathrm{t}-2), \mathrm{Q}(\mathrm{t}-3)\}$ & r \\
\hline $1 \circ Y / I V$ & $40 / 11$ & $\circ / \vee \wedge 9$ & $\uparrow \wedge / \mathrm{VV}$ & $Y N / T Q$ & $\circ / V 99$ & $\mathrm{Q}(\mathrm{t})=\mathrm{f}\{\mathrm{Q}(\mathrm{t}-1), \mathrm{Q}(\mathrm{t}-2), \mathrm{Q}(\mathrm{t}-3), \mathrm{Q}(\mathrm{t}-4)\}$ & r \\
\hline $91 / 10$ & $r 4 / 94$ & $\circ / \wedge \circ \circ$ & $\mathrm{rq} / \mathrm{vq}$ & $4 i / r V$ & 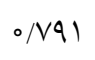 & $\mathrm{Q}(\mathrm{t})=\mathrm{f}\{\mathrm{Q}(\mathrm{t}-1), \mathrm{Q}(\mathrm{t}-2), \mathrm{Q}(\mathrm{t}-3), \mathrm{Q}(\mathrm{t}-4), \mathrm{Q}(\mathrm{t}-5)\}$ & $\Delta$ \\
\hline $\mid r \Delta / \circ \circ$ & $94 / Y 9$ & $\circ / \mathrm{MI}$ & $V Y / \circ V$ & $90 / 9 V$ & $\circ / V Y Q$ & $\mathrm{Q}(\mathrm{t})=\mathrm{f}\{\mathrm{Q}(\mathrm{t}-1), \mathrm{Q}(\mathrm{t}-2), \mathrm{Q}(\mathrm{t}-3), \mathrm{Q}(\mathrm{t}-4), \mathrm{Q}(\mathrm{t}-5), \mathrm{Q}(\mathrm{t}-6)\}$ & 4 \\
\hline
\end{tabular}


جدول ^. تحليل آمارى رگرسيون غيرخطى براى الخوهاى مختلف ورودى ميانخين دبى روزانه در ايستخاه ملاثانى

\begin{tabular}{|c|c|c|c|c|c|c|c|}
\hline \multicolumn{3}{|c|}{ مرحله صحتسنجى } & \multicolumn{3}{|c|}{ مرحله آموزش } & \multirow{2}{*}{ الكوى وروددى روزانه } & \multirow{2}{*}{ شماره } \\
\hline RMSE & MAE & $\mathrm{R}^{2}$ & RMSE & MAE & $\mathrm{R}^{2}$ & & \\
\hline KGY/TG & $90 / 9 r$ & $0 / 9 Y \mid$ & TVN/IY & $99 / \Upsilon^{\circ}$ & $0 / 911$ & $\mathrm{Q}(\mathrm{t})=\mathrm{f}\{\mathrm{Q}(\mathrm{t}-1)\}$ & 1 \\
\hline rTN/qR & $\Lambda V / T \Delta$ & $0 / 949$ & TrYMI & $\Lambda V / Q Y$ &.$/ 94 \lambda$ & $\mathrm{Q}(\mathrm{t})=\mathrm{f}\{\mathrm{Q}(\mathrm{t}-1), \mathrm{Q}(\mathrm{t}-2)\}$ & r \\
\hline $190 / Y r$ & VqRq &.$/ 9 \wedge A^{4}$ & $r 1 \circ / 10$ & $\Lambda r / 9 \Lambda$ &.$/ 909$ & $\mathrm{Q}(\mathrm{t})=\mathrm{f}\{\mathrm{Q}(\mathrm{t}-1), \mathrm{Q}(\mathrm{t}-2), \mathrm{Q}(\mathrm{t}-3)\}$ & r \\
\hline$|\Lambda \mu / 4|$ & $V \circ / V I$ &.$/ 994$ & $19 V / T_{0}$ & $\mathrm{VV} / \circ \circ$ &.$/ 9 V 4$ & $\mathrm{Q}(\mathrm{t})=\mathrm{f}\{\mathrm{Q}(\mathrm{t}-1), \mathrm{Q}(\mathrm{t}-2), \mathrm{Q}(\mathrm{t}-3), \mathrm{Q}(\mathrm{t}-4)\}$ & r \\
\hline $111 / 99$ & $V \circ / T \wedge$ &.$/ 990$ & $1 \wedge Y / r \Delta$ & $V 1 / \mu V$ & $0 / 9 \vee 9$ & $\mathrm{Q}(\mathrm{t})=\mathrm{f}\{\mathrm{Q}(\mathrm{t}-1), \mathrm{Q}(\mathrm{t}-2), \mathrm{Q}(\mathrm{t}-3), \mathrm{Q}(\mathrm{t}-4), \mathrm{Q}(\mathrm{t}-5)\}$ & $\Delta$ \\
\hline$\Delta K M / 10$ & $|r Y /| Y$ &.$/ 01 \mathrm{~V}$ & $94 / Y 4$ & $M N / r^{2}$ & $0 / 9 k \mu$ & $\mathrm{Q}(\mathrm{t})=\mathrm{f}\{\mathrm{Q}(\mathrm{t}-1), \mathrm{Q}(\mathrm{t}-2), \mathrm{Q}(\mathrm{t}-3), \mathrm{Q}(\mathrm{t}-4), \mathrm{Q}(\mathrm{t}-5), \mathrm{Q}(\mathrm{t}-6)\}$ & 4 \\
\hline
\end{tabular}

وجود مقـادير دبسى متنـاظر بـا مقـادير حسداقل جريـان در همسايكى نقطه مورد بيش بينى باشد كـه در عملكـــد مـدل تأثير زيادى داشته است.

بررسى نتايج جدولهاى r تا ها نشان مىدهد كه دقت مـدل

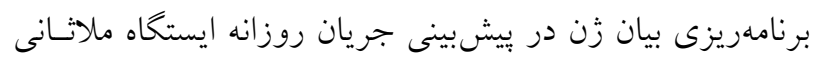
نسبت به ساير روشهاى مورد استفاده در اين تحقيق مطلوبتر بوده است.

بهمنظور بررسى اتــر كنتـرل كنــد كى سـدهاى بالادسـت ايستخاه ملاثانى (جدول 9) بر نتايج بيش بينى ميانخين دبسى روزانه رودخانه كارون، دادههاى ميـانخين روزانـه ايستخاه

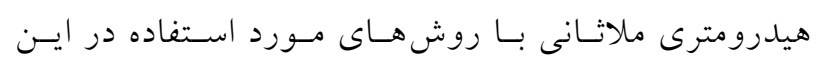
تحقيق ارزيابى شدهاند. براى مثال، تحليل آمارى الكوهـاى مدل برنامهريزى بيان زن بعد از احداث سد شهيد عباسبور براى بيشبينى دبى روزانه ايستخاه ملاثـانى (94-9 وها ) در جدول Vو تحليل آمارى الخوهاى مدل برنامهريزى بيان زن بعد از احداث سد كارون ب بـراى يسيشبينسى دبسى روزانسه ايستخاه ملاثانى (99-94 است. نتايج نشان داد كه بـيش بينسى ميـانكين دبسى جريـان روزانه ايستخاه ملاثانى با استفاده از برنامسه ريـزى بيـان زن

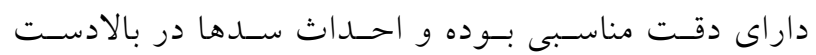
ايستخاه مورد مطالعه با توجه به حجم و شيوه بهرهبـردارى
اين اساس، در مرحله صحتسنجى، روش رگرسيون خطى بـا RMSE = 91/10 $\mathrm{R}^{2}=0 / 100$ بهترى نسبت به رگرسيون غيرخطى داشته است.

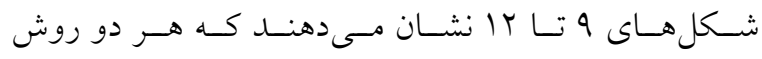
ركرسيونى، ميزان جريان در ايستخاه ملاثانى را در اغلـب مـوارد بيش از مقدار واقعى آن ييشبينى كردهاند. كه ناشى از تشخيص نامناسب بيشبينى تغييرات جريان توسط روشهاى ركرسـيونى است.

نتايج مدلسازى K-NN در اين روش، بيشبينى ميزان جريان، با توجه به تعداد تأخيرهـا و همجينين شعاع همسايكى انجام مىشود. در شكل سا تغييرات و ير اكندگى دادههاى مشاهداتى و يِيشبينى شده جريـان توسـط

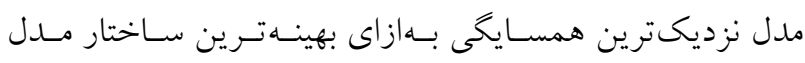
(الكوى ه) نشان داده شده است. نتايج ارائه شـده در جـدول ه ه

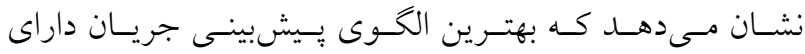
RMSE = $4 q / V \Psi, R^{2}=0 / A r r$ صحتسنجى است.

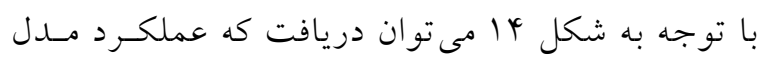
در بيشبينى مقادير حداقل جريان بهمراتب بهتر از بيشبيشى بينى مقادير حداكثر آن بوده كه ايسن مسـئله مسى توانسد ناشسى از 


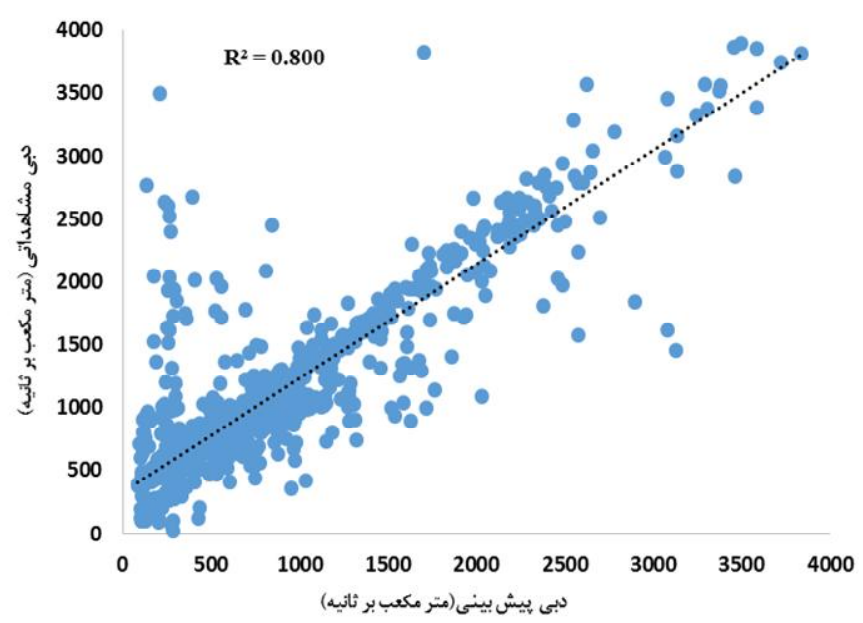

شكل 9. نمودار براكندگى مقادير مشاهداتى و ييشينى شده دبى روزانه ايستخاه ملاثانى با استفاده از رگرسيون خطى در مرحله صحتسنجى

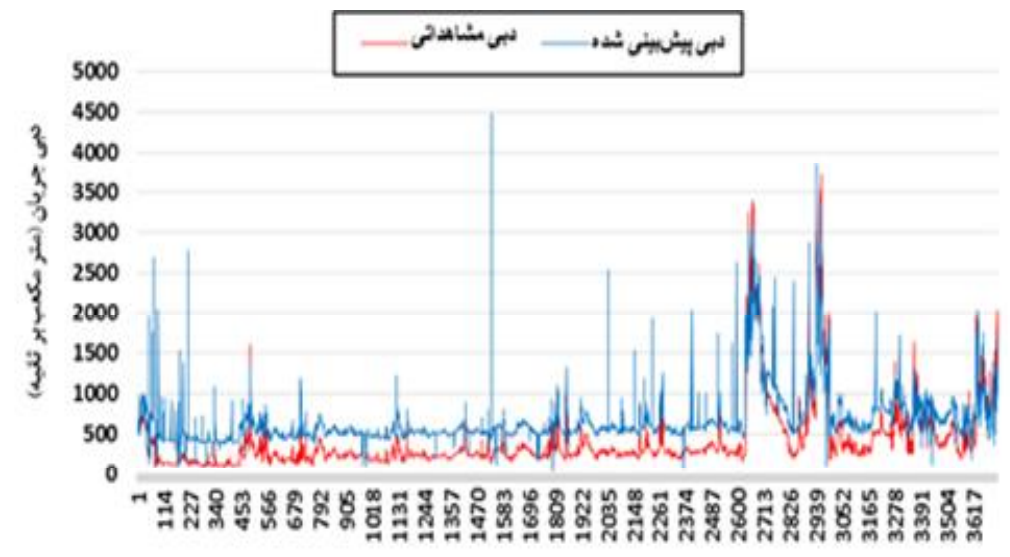

is)

شكل ه ا. مقادير مشاهداتى و ييشبينى شده دبى روزانه ايستخاه ملاثانى با استفاده از ركرسيون خطى در مرحله صحتسنجى (رئ ه (رنخى در نسخه الكترونيكى)

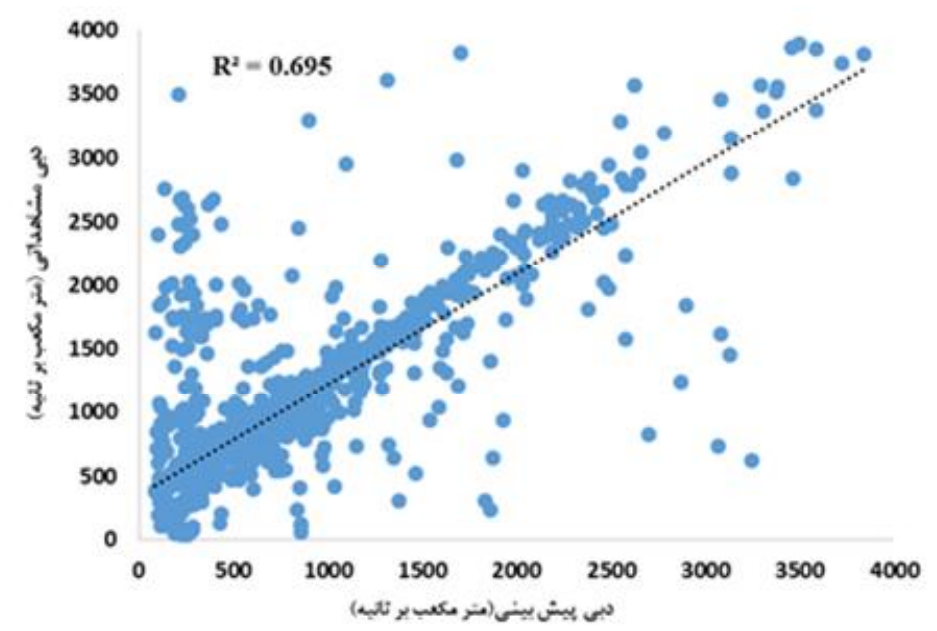

شكل ال. نمودار بر اكندگى مقادير مشاهداتى و ييشينى شده دبى روزانه ايستاه ملاثانى با استفاده از ركرسيون غيرخطى در مرحله صحتسنجى 


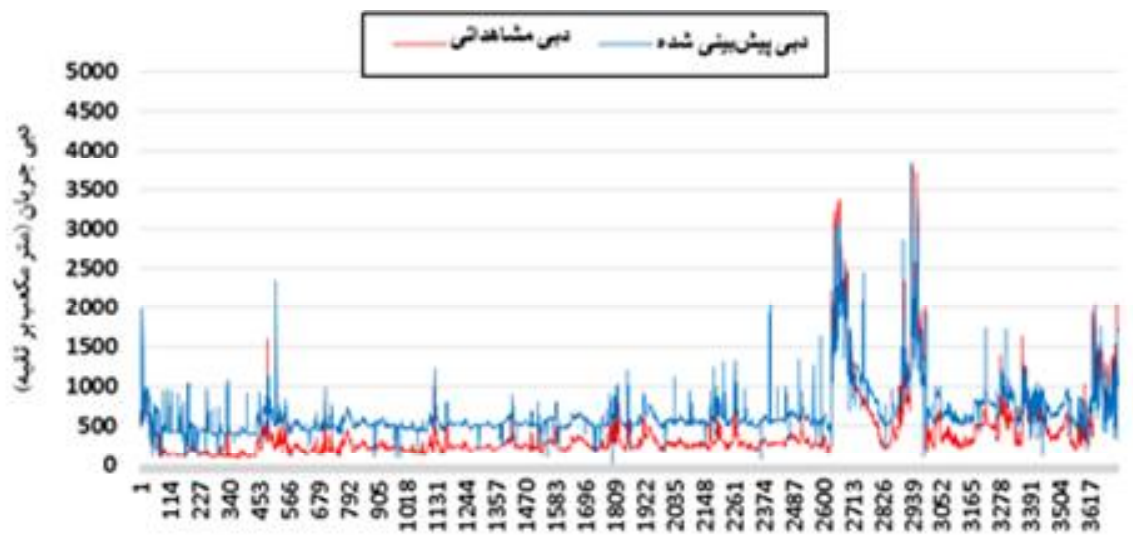

נوز

شكل r ا. مقادير مشاهداتى و بيشبينى شده دبى روزانه ايستخاه ملاثانى با استفاده از رگرسيون غيرخطى در

مرحله صحت سنجى (رنغى در نسخه الكترونيكى)

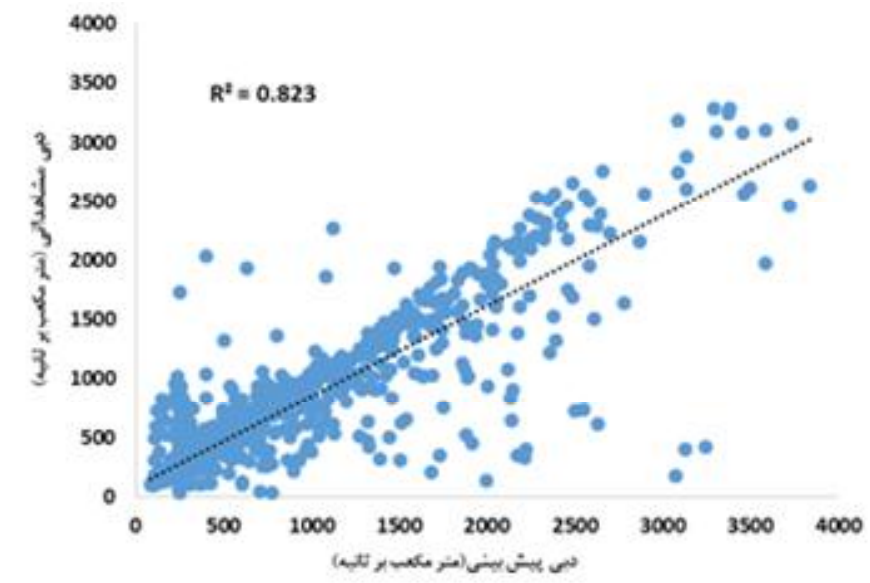

شكل لا ا. نمودار براكندگى مقادير مشاهداتى و بيشبينى شده دبى روزانه ايستخاه ملاثانى با استفاده از الكوريتم K -نزديكترين همسايخى در مرحله صحت سنجى

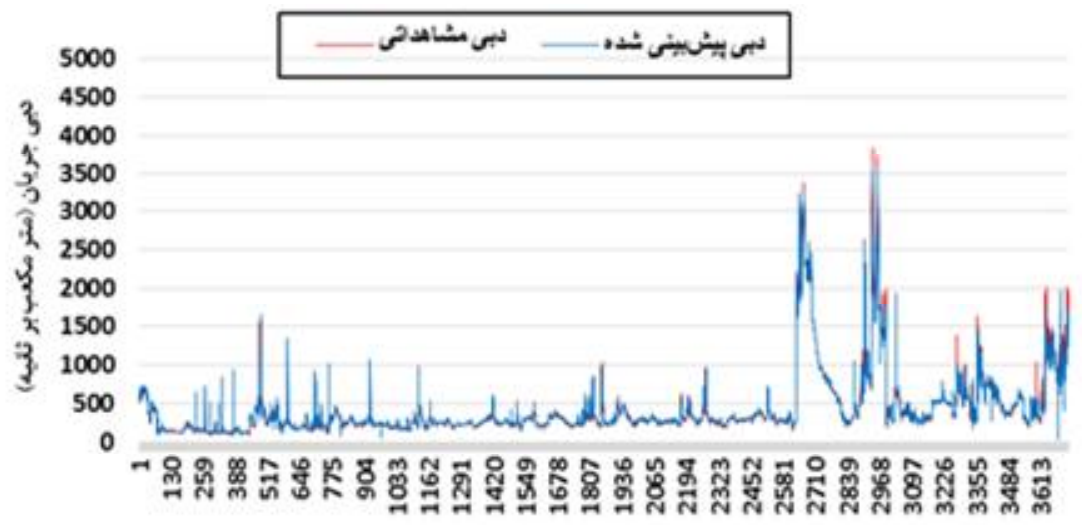

נوز

شكل أ. مقادير مشاهداتى و ييشبينى شده دبى روزانه ايستخاه ملاثانى با استفاده از الكويتم K- نزديكترين همسايخى

در مرحله صحتسنجى (رنخى در نسخه الكترونيكى) 
جدول ه. تحليل آمارى الكوريتم K-NN براى الخوهاى مختلف ورودى ميانگين دبى روزانه در ايستخاه ملاثانى

\begin{tabular}{|c|c|c|c|c|c|c|c|}
\hline \multicolumn{3}{|c|}{ مرحله صحت سنجى } & \multicolumn{3}{|c|}{ مرحله آموزش } & \multirow[t]{2}{*}{ الكوى ورودى روزانه } & \multirow{2}{*}{ شماره } \\
\hline RMSE & MAE & $\mathrm{R}^{2}$ & RMSE & MAE & $\mathrm{R}^{2}$ & & \\
\hline $\mid 49 / 04$ & $\Lambda \circ / \Delta r$ & o/vor & $r \circ \Delta / 4 I$ & MNG & $\circ / V \circ V$ & $\mathrm{Q}(\mathrm{t})=\mathrm{f}\{\mathrm{Q}(\mathrm{t}-1)\}$ & 1 \\
\hline $\mid K T / V 0$ & $V N / \circ \circ$ & $\circ / V Q 9$ & $191 / 41$ & $\Lambda r / \varphi_{0}$ & $\circ / N H$ & $\mathrm{Q}(\mathrm{t})=\mathrm{f}\{\mathrm{Q}(\mathrm{t}-1), \mathrm{Q}(\mathrm{t}-2)\}$ & r \\
\hline $1 \Pi \pi / \Delta \Delta$ & $V Q / N r$ & $\circ / \mathrm{V} Q \Lambda$ & $100 / 11$ & $91 / 90$ & -/VQr & $\mathrm{Q}(\mathrm{t})=\mathrm{f}\{\mathrm{Q}(\mathrm{t}-1), \mathrm{Q}(\mathrm{t}-2), \mathrm{Q}(\mathrm{t}-3)\}$ & r \\
\hline $100 / 14$ & $99 / \pi r$ & $\circ / \mathrm{N} \wedge$ & $\mid r r / \circ$ & $99 / 4 T$ & o/VGr & $\mathrm{Q}(\mathrm{t})=\mathrm{f}\{\mathrm{Q}(\mathrm{t}-1), \mathrm{Q}(\mathrm{t}-2), \mathrm{Q}(\mathrm{t}-3), \mathrm{Q}(\mathrm{t}-4)\}$ & r \\
\hline $4 q / Y^{k}$ & $r V / r q$ & o/Arr & $9 / / 41$ & $91 / 19$ & $\circ / \Lambda \mid Y$ & $\mathrm{Q}(\mathrm{t})=\mathrm{f}\{\mathrm{Q}(\mathrm{t}-1), \mathrm{Q}(\mathrm{t}-2), \mathrm{Q}(\mathrm{t}-3), \mathrm{Q}(\mathrm{t}-4), \mathrm{Q}(\mathrm{t}-5)\}$ & $\Delta$ \\
\hline $10 \mathrm{r} / \mathrm{Aq}$ & $\Lambda 1 / \mu$ & $\circ / N 4$ & $194 / 94$ & $91 / 49$ & $\circ / \mathrm{r} \circ \mathrm{r}$ & $\mathrm{Q}(\mathrm{t})=\mathrm{f}\{\mathrm{Q}(\mathrm{t}-1), \mathrm{Q}(\mathrm{t}-2), \mathrm{Q}(\mathrm{t}-3), \mathrm{Q}(\mathrm{t}-4), \mathrm{Q}(\mathrm{t}-5), \mathrm{Q}(\mathrm{t}-6)\}$ & 4 \\
\hline
\end{tabular}

جدول 9. نام سدهاى مخزنى ساخته شده در بالادست ايستخاه هيدرومترى ملاثانى و زمان بهرهبردارى از آنها

\begin{tabular}{|c|c|c|c|c|}
\hline محل قرارگيرى سد & (مجليارد متر مخعنب) & زمان بهرهبردارى & 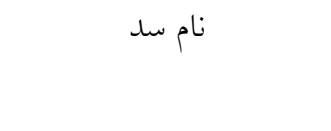 & رديف \\
\hline شاخه دز رودخانه كارون بزرگ & $\mu / \mu_{0}$ & 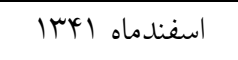 & دز & 1 \\
\hline شاخه كارون رودخانه كارون بزرگ & $r / l 4$ & آذرماه فهاس & شهيد عباسيور (كارون () & r \\
\hline شاخه كارون رودخانه كارون بزرگ & r/。 。 & 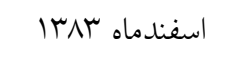 & كارون r - ك & r \\
\hline شاخه كارون رودخانه كارون بزرگ & $r / 90$ & فروردين ماه مش|| & مسجد سليمان (كدار لندر) & r \\
\hline شاخه كارون رودخانه كارون بزرى & $\varphi / \Delta_{0}$ & مردادماه هوس & كُتوند عليا & 0 \\
\hline
\end{tabular}

جدول V. تحليل آمارى الخوهاى مدل برنامهريزى بيان زّن بعد از احداث سد شهيد عباسبور براى بيشبينى ميانگين دبى روزانه ايستخاه ملاثانى (IrDs-99)

\begin{tabular}{|c|c|c|c|c|c|c|c|}
\hline \multicolumn{3}{|c|}{ مرحله صحتسنجى } & \multicolumn{3}{|c|}{ 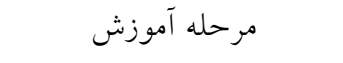 } & \multirow[t]{2}{*}{ الخوى ورودى روزانه } & \multirow{2}{*}{ شماره } \\
\hline RMSE & MAE & $\mathrm{R}^{2}$ & RMSE & MAE & $\mathrm{R}^{2}$ & & \\
\hline $99 / 91$ & TV/O。 & $\circ / 1 / 0$ & $V Q / 19$ & $r Q / I T$ & $0 / 119$ & $\mathrm{Q}(\mathrm{t})=\mathrm{f}\{\mathrm{Q}(\mathrm{t}-1)\}$ & 1 \\
\hline$\Delta M / I 1$ & $r \circ / l V$ & o/ATt & $99 / 4 r$ & $r r / 4 q$ & $0 / 119$ & $\mathrm{Q}(\mathrm{t})=\mathrm{f}\{\mathrm{Q}(\mathrm{t}-1), \mathrm{Q}(\mathrm{t}-2)\}$ & r \\
\hline rq/०。 & $14 / 0 \wedge$ & $0 / \Lambda \& \mid$ & $4 r / 99$ & $19 / T^{C}$ & $\circ / \Lambda \mu_{0}$ & $\mathrm{Q}(\mathrm{t})=\mathrm{f}\{\mathrm{Q}(\mathrm{t}-1), \mathrm{Q}(\mathrm{t}-2), \mathrm{Q}(\mathrm{t}-3)\}$ & r \\
\hline$\mu_{\circ / 9 V}$ & $14 / 01$ & $\circ / \Lambda \Delta 4$ & $41 / 11$ & $19 / 01$ & •/Ard & $\mathrm{Q}(\mathrm{t})=\mathrm{f}\{\mathrm{Q}(\mathrm{t}-1), \mathrm{Q}(\mathrm{t}-2), \mathrm{Q}(\mathrm{t}-3), \mathrm{Q}(\mathrm{t}-4)\}$ & i \\
\hline Kr/vo & $19 / 70$ & $\circ / \Lambda r V$ & $4 q / 94$ & $T I / 9 \mathrm{~V}$ & o/AYY & $\mathrm{Q}(\mathrm{t})=\mathrm{f}\{\mathrm{Q}(\mathrm{t}-1), \mathrm{Q}(\mathrm{t}-2), \mathrm{Q}(\mathrm{t}-3), \mathrm{Q}(\mathrm{t}-4), \mathrm{Q}(\mathrm{t}-5)\}$ & $\Delta$ \\
\hline$\Lambda Q / 9 T$ & $49 / 0 \mathrm{r}$ & $\circ / \mathrm{V} 99$ & $9 \pi / 0 F$ & $09 / 1 \mathrm{~V}$ & $\circ / \mathrm{VqF}$ & $\mathrm{Q}(\mathrm{t})=\mathrm{f}\{\mathrm{Q}(\mathrm{t}-1), \mathrm{Q}(\mathrm{t}-2), \mathrm{Q}(\mathrm{t}-3), \mathrm{Q}(\mathrm{t}-4), \mathrm{Q}(\mathrm{t}-5), \mathrm{Q}(\mathrm{t}-6)\}$ & 4 \\
\hline
\end{tabular}


جدول ^ـ تحليل آمارى الكوهاى مدل برنامهريزى بيان زُن بعد از احداث سد كارون ب براى ييشبينى ميانغين دبى روزانه ايستخاه ملاثانى (Y)-94F)

\begin{tabular}{|c|c|c|c|c|c|c|c|}
\hline \multicolumn{3}{|c|}{ مرحله صحتسنجى } & \multicolumn{3}{|c|}{ مرحله آموزش } & \multirow[t]{2}{*}{ الخ الخوى ورودى روزانه } & \multirow{2}{*}{ شماره } \\
\hline RMSE & MAE & $\mathrm{R}^{2}$ & RMSE & MAE & $\mathrm{R}^{2}$ & & \\
\hline$V Q / Y Y$ & $|4 \& / r|$ & oVGr & $\mid r Y / 94$ & $91 / \mathrm{M}$ & o/NYY & $\mathrm{Q}(\mathrm{t})=\mathrm{f}\{\mathrm{Q}(\mathrm{t}-1)\}$ & 1 \\
\hline $9 Y / 9 V$ & $\psi V / r_{0}$ & $\circ / N Q 9$ & $119 / .9$ & $\Delta V / \circ \Delta$ & $\circ / N \Delta 9$ & $\mathrm{Q}(\mathrm{t})=\mathrm{f}\{\mathrm{Q}(\mathrm{t}-1), \mathrm{Q}(\mathrm{t}-2)\}$ & r \\
\hline$\Delta F / T)$ & $r a / 11$ & $\circ / V \Lambda F$ & $\Lambda \Delta / r)$ & $\Delta 1 / \circ \circ$ & $\circ / \sqrt{91}$ & $\mathrm{Q}(\mathrm{t})=\mathrm{f}\{\mathrm{Q}(\mathrm{t}-1), \mathrm{Q}(\mathrm{t}-2), \mathrm{Q}(\mathrm{t}-3)\}$ & r \\
\hline$\Delta F / \circ \wedge$ & $\Pi \pi / v a$ & $\circ / V A V$ & $94 \% 0$ & $r Y / \Lambda 9$ &.$/ \mathrm{V} 99$ & $\mathrm{Q}(\mathrm{t})=\mathrm{f}\{\mathrm{Q}(\mathrm{t}-1), \mathrm{Q}(\mathrm{t}-2), \mathrm{Q}(\mathrm{t}-3), \mathrm{Q}(\mathrm{t}-4)\}$ & $r$ \\
\hline $9 N / I V$ & $4 / / 09$ & ०/V9a & $v g / T V$ & $19 / 19$ & $\circ / \mathrm{V} 9 \mathrm{O}$ & $\mathrm{Q}(\mathrm{t})=\mathrm{f}\{\mathrm{Q}(\mathrm{t}-1), \mathrm{Q}(\mathrm{t}-2), \mathrm{Q}(\mathrm{t}-3), \mathrm{Q}(\mathrm{t}-4), \mathrm{Q}(\mathrm{t}-5)\}$ & 0 \\
\hline$v r / r r$ & $01 / 00$ & $\circ / V Q 1$ & va/qr & $\Delta r / r q$ & $\circ / N Y_{Y}$ & $\mathrm{Q}(\mathrm{t})=\mathrm{f}\{\mathrm{Q}(\mathrm{t}-1), \mathrm{Q}(\mathrm{t}-2), \mathrm{Q}(\mathrm{t}-3), \mathrm{Q}(\mathrm{t}-4), \mathrm{Q}(\mathrm{t}-5), \mathrm{Q}(\mathrm{t}-6)\}$ & 4 \\
\hline
\end{tabular}

جدول 9. بيشبينى مقادير حداكثر جريان ايستخاه ملاثانى با مدلهاى مورد استفاده و درصد خطاى نسبى متناظر با آنها

\begin{tabular}{|c|c|c|c|c|c|c|c|c|c|c|}
\hline $\begin{array}{l}\text { خطاى نسبى الكوريتم } \\
\text { K-NN } \\
\text { K-NN }\end{array}$ & خرخاى نسبى خرسيون & خرخاى نسبى خرسيون & بربام بامريزى نسبى & $\begin{array}{l}\text { الكوريتم } \\
\text { K-NN } \\
\left(\mathrm{m}^{3} / \mathrm{s}\right)\end{array}$ & $\begin{array}{l}\text { رخرسيون } \\
\text { غيرخطى } \\
\left(m^{3} / s\right)\end{array}$ & $\begin{array}{c}\text { رخرسيون } \\
\text { خطى } \\
\left(m^{3} / s\right)\end{array}$ & برنامهريزى & تاريخ & جراكثر & رديف \\
\hline$-r / l r$ & $-r Q / / T$ & $-19 / \circ V$ & $-r / \mu r$ & TMM & rir。 & TyMT & raro & |raT/MITA & $r \circ \circ \Delta$ & 1 \\
\hline$-11 / 94$ & re/T\& & $r \circ / 4 q$ & $-9 / \pi r$ & 1004 & rifa & $r$ rMa & 1099 & $|r q r / 0| / 1 V$ & IVor & r \\
\hline$-9 / N G$ & $-r 1 / 99$ & $-11 / v 9$ & $-9 / 4 V$ & roYs & rria & rQTS & rorv & $1 r q 4 / 01 / 19$ & MTYV & r \\
\hline$\Delta / N T$ & $9 / 91$ & IN/TY & $r / r v$ & mov & rYQO & rvite & TMYS & $\mid r q 4 / \| 1 / 4$ & mira & $r$ \\
\hline$-1 / 10$ & $-r_{0} / 99$ & $-9 / 9 \mathrm{~V}$ & $-\circ / v a$ & IrVG & 1104 & $1 r 90$ & $\left|r_{N}\right|$ & $1 \% 90 / 10 / 10$ & Irar & 0 \\
\hline$-0 / 91$ & $-19 / 0 r$ & $-V / \Delta \omega$ & $-r / 4 \varphi$ & 1914 & 1419 & 1009 & lovr & $\mid r 99 / 01 / 01$ & 1949 & 9 \\
\hline$-9 / 49$ & $-19 / 09$ & $-10 / \mu r$ & $-r / 40$ & $19 . r$ & IVor & 1219 & 1990 & $\mid r q 9 / 10 \%$ & ror. & v \\
\hline$\Delta / r r$ & TI/AY & $1 N / \circ D$ & $r / N$ & \multicolumn{7}{|c|}{ متوسط قدر مطلق خطا } \\
\hline
\end{tabular}

از آنها، تأثير قابل ملاحظهاى بر دقـت يـيش بينسى مطلـوب بروسى دقت مدلها در بيشبينى حداكثر جريان

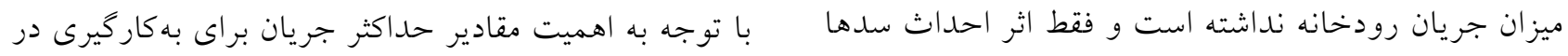

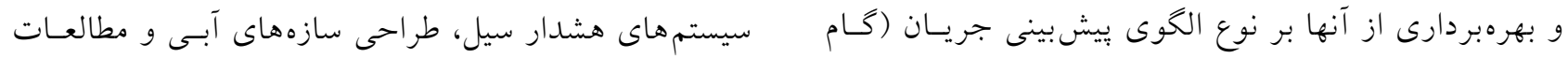

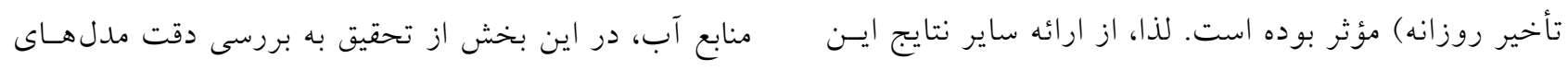

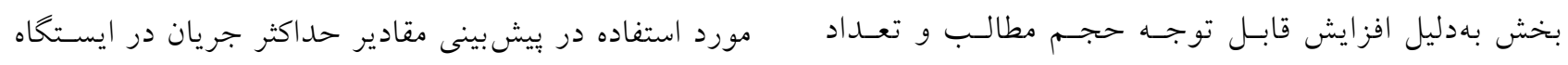

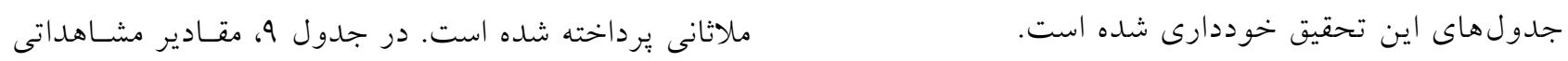


باييندست ينج مخزن بزرگ و نيز دو شاخه مجزاى رودخانه

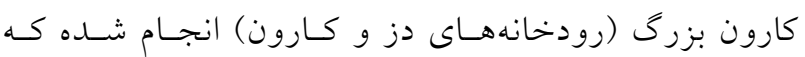

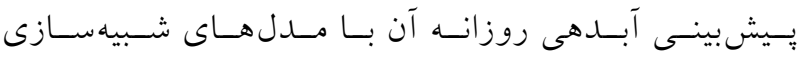

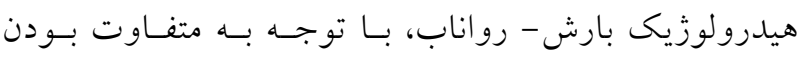

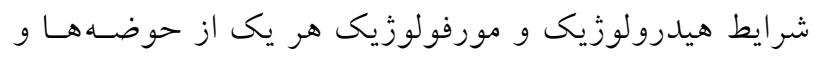

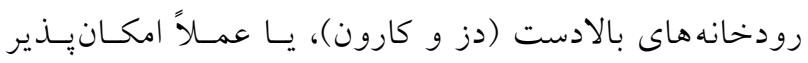

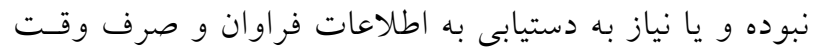

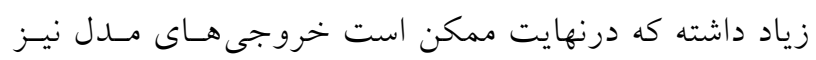

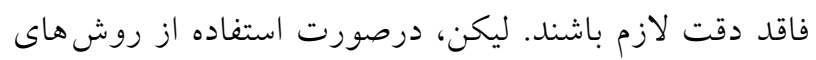
دادهمبنا در اين تحقيق، مى توان با صرف وقت اندى و داشتن

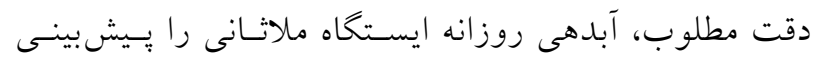

\section{نتيجه گيرى}

در اين مطالعه، به بررسى عملكـــد مــدل برنامـهريـزى بيـان زن

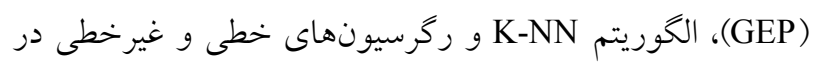

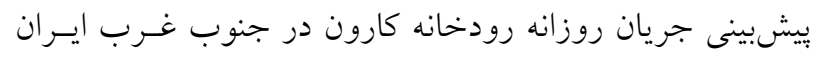

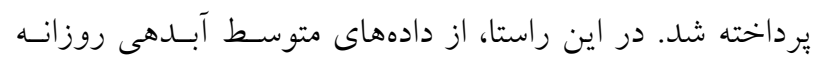

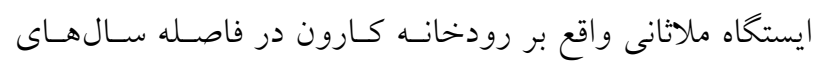

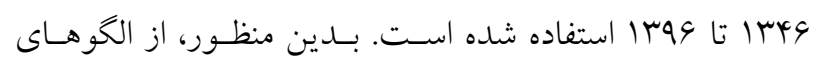

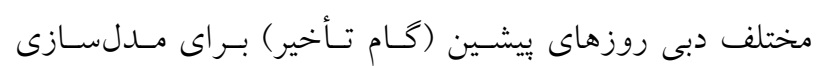
استفاده شد. در مدلهاى استفاده شده در ايسن تحقيـق، بهترين

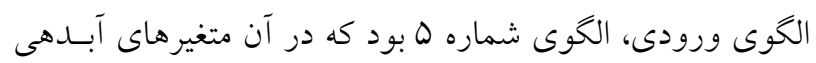

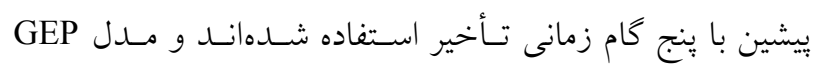

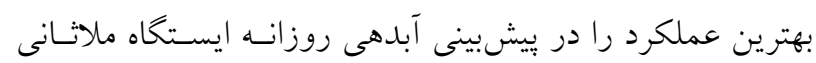

$$
\text { داشته است. }
$$

با توجه به اهميت مقادير حداكثر جريان در مــيريت منـابع

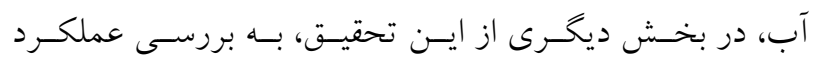

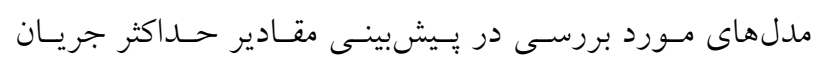

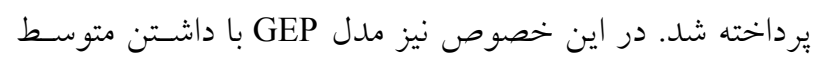

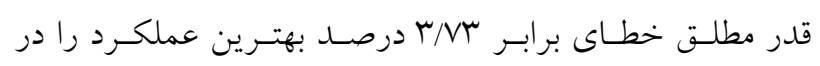

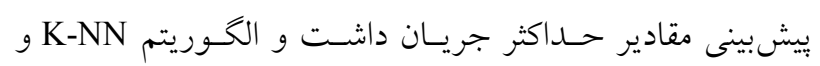

حداكثر جريان و مقادير ييش بينى شده با مدلهاى مختلف و

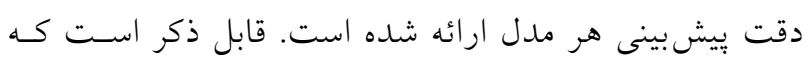

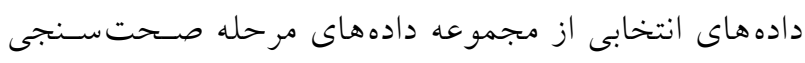

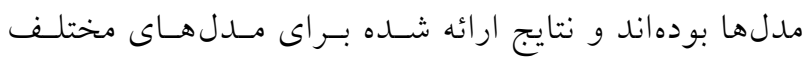

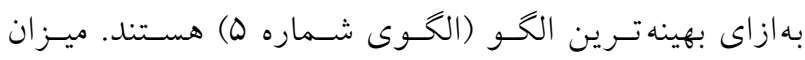
خطاى نسبى نيز از رابطه بأ محاسبه شده است:

$\mathrm{RE}=\frac{\mathrm{Q}_{\mathrm{P}}-\mathrm{Q}_{\mathrm{O}}}{\mathrm{Q}_{\mathrm{O}}}$

كه Qo مقدار دبى مشاهداتى و Qp مقدار دبسى يـيشبينى شــه تغييرات ميزان متوسط قـــر مطلـق خطــا بــراى مقــادير

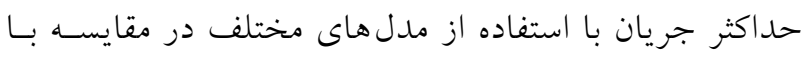
مقادير مشاهداتى در جدول 9 نشان داده شده اسـت. از ايسن

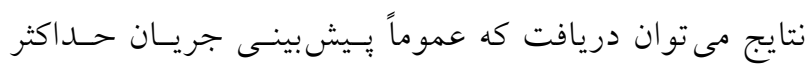
توسط مدل هاى مختلف كمتر از مقادير مشاهداتى بـوده كـهـ ممكن است اين امر ناشى از ماهيت تصادفى مقادير حـداكثر

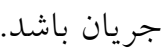
نتايج جدول 9 نشان مى دهد كه گرجهه مدل برنامهريزى بيان زن و الكوريتم K- نزديكترين همسايكى در رابطه با بيشبينس

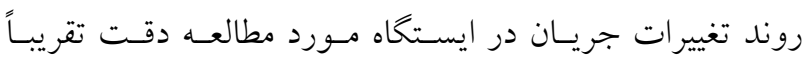
يكسانى داشتهاند، ليكن در مورد بيشبينى دبى حسداكثر جريسان

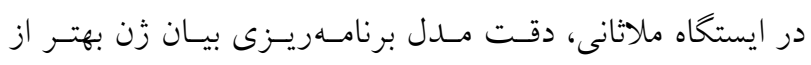

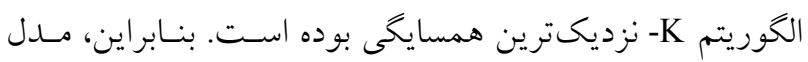

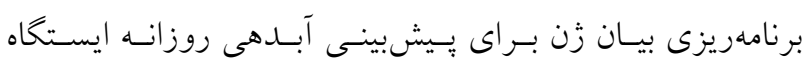
ملاثانى بيشنهاد مىشود.

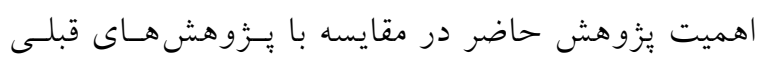

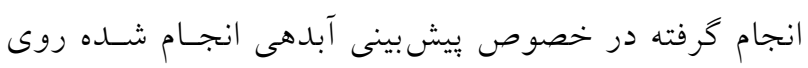

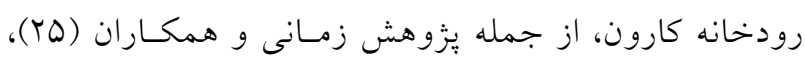

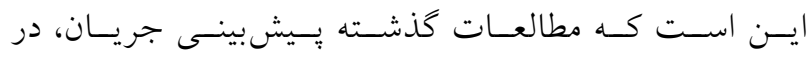
ايستخاه هاى بالادست مخازن موجـود روى ايسن رودخانسه و

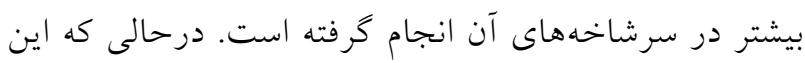

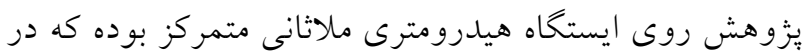




$$
\begin{aligned}
& \text { روش هاى ركرسيون خطى و غيرخطى در اولويـتهــاى بعـدى از مدل برنامهريزى بيان زن، بـهعلـت دقـت قابـل قبـول و نيـز }
\end{aligned}
$$

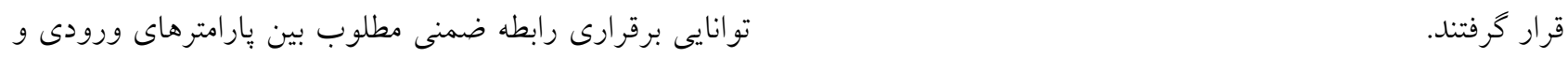

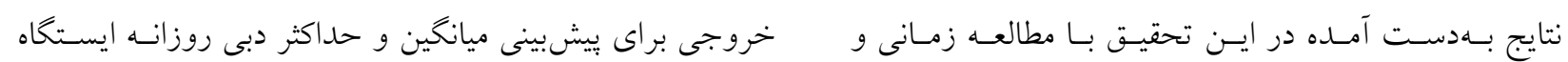

$$
\begin{aligned}
& \text { همكاران (TO) در سرشـاخههـاى كـارون و نيـز امـامقلىزاده و ملاثنى بيشنهاد مى شود. } \\
& \text { همكاران (9) در حوضه آبريز كسيليان مطابقت دارد. لذا استغاده }
\end{aligned}
$$

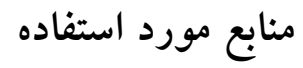

1. Aalami, M. T., S. Sadeghfam and M. H. Fazelifard. 2013. Time Series Modeling. Tabriz University. (In Farsi).

2. Aleyasin, A. 2000. Applied River Engineering in Dez and Karun Rivers. Ministry of Energy, Tehran. (In Farsi).

3. Ahani, A. and M. Shourian. 2017. Prediction of monthly streamflow using data driven models . Journal of IranWater Resources Research 13(2): 207-214. (In Farsi).

4. Azmi, M. and Sh. Araghinejad. 2012. Developed K-nearest neighbor method for river flow prediction. Journal of Water and Wastewater 2: 108-119. (In Farsi).

5. Dasarathy, B. V. 1991. Nearest Neighbor (NN) Norms: NN Pattern Classification Techniques. IEEE Computer Society Press, Los Alamitos, CA.

6. Emamgolizadeh, S., R. Karimi Damaneh and H. Mehdipanah. 2016. Estimation of Kasilian watershed runoff by gene expression programming. International Conference on Sustainable Agriculture, Environment and Rural Development, Tehran, Iran. (In Farsi).

7. Ferreira, C. 2001. Gene expression programming: A new adaptive algorithm for solving problems. Complex Systems 13(2): 87-129.

8. Govindaraju, R. S. 2000. Artificial neural network in hydrology. Journal of Hydrologic Engineering 5(2): 115-123.

9. Güçlü, Y. S. 2018. Multiple Şen-innovative trend analyses and partial Mann-Kendall test. Journal of Hydrology 566: 685-704.

10. Karamouz, M. and Sh. Araghinejad. 2011. Advanced Hydrology. $2^{\text {nd }}$ ed., Amirkabir University of Technology, Tehran, Iran. (In Farsi).

11. Khedmati, H., M. Manshouri, M. Heydarizadeh and H. Sedghi. 2010. Zonation and estimation of flood discharge in unguaged sites located in south-east basins of Iran using a combination of flood index and multi-variable regression methods (Sistan and Baluchistan, Kerman, Yazd and Hormozgan provinces). Journal of Water and Soil 24(3): 593906. (In Farsi).

12. Kim, U. and J. J. Kaluarachchi. 2008. Application of parameter estimation and regionalization methodologies to ungauged basins of the Upper Blue Nile River Basin, Ethiopia. Journal of Hydrology 362: 39-56.

13. Kisi, O. 2007. Streamflow forecasting using different artificial neural network algorithms. ASCE, Journal of Hydrologic Engineering 12(5): 532-539.

14. Kottegoda, N., L. Natale and E. Raiteri. 2004. Some considerations of periodicity and persistence in daily rainfalls. Journal of Hydrology 296: 23-37.

15. Omidvarinia, M. 2009. Application of genetic algorithm to optimize the dimensionless input parameters of artificial neural network to estimate suspended load in alluvial rivers. Ph.D Dissertation, Shahid Chamran University, Ahvaz, Iran. (In Farsi).

16. Pande, S., M. McKee and L. A. Bastidas. 2009. Complexity-based robust hydrologic prediction. Water Resources Research 45: W10406.

17. Ren, J., B. Ren, Q. Zhang and X. Zheng. 2019. A novel hybrid extreme learning machine approach improved by K nearest neighbor method and fireworks algorithm for flood forecasting in medium and small watershed of loess region. Water 11(9): 1848.

18. Sette, S. and L. Boullart. 2001. Genetic programming: Principles and applications. Engineering Applications of Artificial Intelligence 14: 727-736.

19. Sharifazari, S. and Sh. Araghinejad. 2013. Develop a non-parametric model to simulate monthly hydrological data. Journal of Water and Irrigation Management 1(3): 83-95. (In Farsi).

20. Sharma, A. and U. Lall. 1999. A nonparametric approach for daily rainfall simulation. Mathematics and Computers in Simulation 48: 361-371.

21. Soltani, A., M. A. Gorbani, A. Fakheri Fard, S. Darbandi and D. Farsadizadeh. 2011. Genetic programming and its application in rainfall-runoff modeling. Journal of Water and Soil Science 20(4): 62-71. (In Farsi). 
22. Sun, L., I. Nistor, O. Seidou, S. Sambou, C. M. F. Kebe and S. Tamba. 2013. Prediction of daily discharge at Bakel (Senegal) using multiple linear regression, Kalman filter and artificial neural networks. In: $3^{\text {rd }}$ Specialty Conference on Disaster Prevention and Mitigation, DIS-15-1: 9-15.

23. Tsakiri, K., A. Marsellos and S. Kapetanakis. 2018. Artificial neural network and multiple linear regression for flood prediction in Mohawk River, New York. Water 10(9): 1158.

24. Wu, C. L. and K. W. Chau. 2010. Data-driven models for monthly streamflow time series prediction. Engineering Applications of Artificial Intelligence 23: 1350-1367.

25. Zamani, R., F. Ahmadi and F. Radmanesh. 2015. Comparison of the gene expression programming, nonlinear time series and artificial neural network in estimating the river daily flow (Case study: The Karun river). Journal of Water and Soil 28(6): 1172-1182.

26. Zorn, C. R. and A. Y. Shamseldin. 2015. Peak flood estimation using gene expression programming. Journal of Hydrology 531: 1122-1128. 


\title{
Comparison of Gene Expression Programming (GEP) and Parametric and Non-parametric Regression Methods in the Prediction of the Mean Daily Discharge of Karun River (A case Study: Mollasani Hydrometric Station)
}

\author{
M. Alinezhadi, S. F. Mousavi ${ }^{*}$ and Kh. Hosseini ${ }^{1}$
}

(Received: March 7-2020 ; Accepted: August 5-2020)

\begin{abstract}
Nowadays, the prediction of river discharge is one of the important issues in hydrology and water resources; the results of daily river discharge pattern could be used in the management of water resources and hydraulic structures and flood prediction. In this research, Gene Expression Programming (GEP), parametric Linear Regression (LR), parametric Nonlinear Regression (NLR) and non-parametric K- Nearest Neighbor (K-NN) were used to predict the average daily discharge of Karun River in Mollasani hydrometric station for the statistical period of 1967-2017. Different combinations of the recorded data were used as the input pattern to predict the mean daily river discharge. The obtained esults indicated that GEP, with $\mathrm{R}^{2}=0.827, \mathrm{RMSE}=59.45$ and $\mathrm{MAE}=26.64$, had a better performance, as compared to LR, NLR and K-NN methods, at the validation stage for daily Karun River discharge prediction with 5-day lag, at the Mollasani station. Also, the performance of the models in the maximum discharge prediction showed that all models underestimated the flow discharge in most cases.
\end{abstract}

Keywords: River discharge, Gene expression programming, Linear and nonlinear regression, K- nearest neighbor, Karun.

1- Department of Water Engineering and Hydraulic Structures, Faculty of Civil Engineering, Semnan University, Semnan, Iran.

Corresponding author, Email: fmousavi@semnan.ac.ir 